\title{
Impacts of red meat production on biodiversity in Australia: a review and comparison with alternative protein production industries
}

\author{
J. E. Williams ${ }^{\mathrm{A}, \mathrm{C}}$ and R. J. Price ${ }^{\mathrm{B}}$ \\ AManaging Director, NRM Insights, PO Box 3263 UMDC, Ulverstone, Tas. 7315; Adjunct Professor, Tasmanian \\ Institute of Agricultural Research, University of Tasmania, Private Bag 3523, Burnie, Tas. 7001, Australia. \\ ${ }^{B}$ Managing Director, Kiri-ganai Research, GPO Box 103, Canberra, ACT 2601; Adjunct Fellow, Fenner School of \\ Environment and Society, Australian National University, Canberra, ACT 0200, Australia. \\ ${ }^{\mathrm{C}}$ Corresponding author. Email: jann@nrminsights.com.au
}

\begin{abstract}
All food production systems are under pressure to comply with societal expectations that the produce is not only of good nutritional value but is also sustainably produced. This review compares the performance of the red meat industry in Australia against white meat, plant-protein and other protein production systems across a range of biodiversity pressures through a review of over 500 peer-reviewed and other scientific sources. The review finds that taking into account the past legacy of red meat production systems, these industries make the largest relative potential contribution to the impact on terrestrial biodiversity in Australia, by both the area covered and the nature of the impacts. The review also finds that many initiatives of the beef and sheep industries have the potential to improve the management of biodiversity. To minimise the impact of beef and sheep meat systems on biodiversity, the conservation of natural resources needs to become a core and integral part of production systems, rather than it being perceived as an optional extra if times are good. To help address these challenges, stewardship payments for the ecosystem services (such as carbon, water and biodiversity) provided by the farming community to the wider society warrant further consideration.
\end{abstract}

Additional keywords: food, pressures.

\section{Introduction}

The beef and sheep industries in Australia have been critical in the development and shaping of Australia from the time of the First Fleet. They have played a significant role in the economic fortunes of the nation in the past and continue to make a major contribution, particularly in the export market. They have also played an important role in the psyche of Australia and in defining the character of the Australian 'outback' culture, as well as helping shape the typical Australian diet. The Australian beef and lamb/ mutton industries continue to grow on increasing demand domestically and internationally for red meat (ABARE 2007a).

The National Health and Medical Research Council (NHMRC) of Australia includes cattle, sheep, goats and kangaroos in their definition of red meat (NHMRC 2003), a definition we adopt in this review. National dietary guidelines indicate that 3-4 serves of lean red meat a week can provide easily digestible and high-quality protein, as well as a range of important and accessible nutrients such as iron, zinc and Vitamin $B_{12}$ (NHMRC 2003). Diets that don't include red meat, including vegetarian diets, can provide the same range of nutrients through the consumption of a broader range of foods and supplementation for nutrients found only in animal products (NHMRC 2003).

In addition to being an important economic and cultural force, the cattle and sheep industries have left a lasting impact on the biodiversity of Australia. This includes the direct impacts of land clearing for conversion to exotic pastures, as well as overgrazing (particularly in drought conditions) and trampling, which can have major impacts on soil, including the loss of soil and biological crusts, erosion and compaction. Indirect impacts include pressures such as the introduction of environmental weeds, changes to fire regimes and altered hydrological flows. Because the grazing industry covers a large area of Australia, these impacts are widespread and have captured the attention of the public.

The major protein alternatives to beef and sheep meat consumed in Australia are chicken, pork, eggs, dairy products and fish. Emerging industries include goats (mainly exports) and kangaroos, which currently contribute a small proportion to the economy. Grains and pulses also contribute protein to the Australian diet, both directly through human consumption and indirectly through the feeding of grain to animals, especially in the feedlot industry. Each of these protein sources have an impact on biodiversity, sometimes in similar and sometimes in very different ways to the red meat industry.

With increasing consumer attention paid not only to the nutritional value of what they eat, but also to how it is produced (Stringer and Anderson 2001), this paper provides a review to establish the evidence base for the performance of the red meat sector in respect to biodiversity management. It seeks to establish the impacts - positive and negative, historical and 
current, direct and indirect, aquatic and terrestrial - of the beef and sheep meat industries on Australia's biodiversity, and, as far as possible, compare these impacts with other major alternative dietary protein production systems in Australia. The approach taken in this paper is to identify the main pressures on biodiversity across different protein sources, then compare the contribution of each protein source to these pressures.

\section{Biodiversity and historical legacy in Australia}

It has been argued that most of the pressures and impacts on biodiversity related to agriculture in Australia occurred in the past, when our understanding of impacts was less, community expectation were different and some laws (e.g. compulsory land clearing) were enacted to help the development of the country (Lunney 2001). These past pressures often have a lasting legacy that will continue for decades to come, even with remedial action. This response is often referred to as an extinction debt, a concept introduced by Tilman et al. (1994) and refined and tested since (e.g. Loehle and Li 1996; Cogger et al. 2003; Helm et al. 2006; Mac Nally et al. 2009). Consequently, despite identifying some encouraging signs at local to regional scales, Beeton et al. (2006) indicated that biodiversity continues to be in serious decline in many parts of Australia. Examples of the ongoing declines of species have been reported by several authors, particularly for birds and mammals in the rural landscapes of south-eastern Australia (Ford et al. 2001; Radford et al. 2005; Mac Nally et al. 2009), including where areas have been revegetated (Vesk and Mac Nally 2006).

Studies such as Lunt and Spooner (2005) have highlighted the over-riding influence of land-use history in creating past, current and future patterns of biodiversity across a range of spatial scales in south-eastern Australia. They argued that the more we know about the history of landscapes, the better we will be able to understand, describe, predict and manage patterns of remnant woodland vegetation and associated biota. Burgman et al. (2007), analysing data on endangered flora, found that the primary causes of range contractions and habitat loss in the past (land clearance for agriculture - grazing and cropping - and urbanisation) are responsible for the current status of the majority of threatened Australian plants. They argued that in the future, many species are at risk from demographic and environmental uncertainty alone, which is often related to the legacy of management practices such as vegetation clearance. These examples demonstrate that both historical and current land use management have ongoing impacts on biodiversity and cannot always be easily separated, even when management actions have improved and remediation activities are in place.

Historical legacy is considered in this paper in the interest of providing comprehensive consideration of the impacts of different protein sources on biodiversity.

\section{Methods}

\section{Scope and selection process}

This study focuses on Australian protein production systems, across terrestrial and aquatic environments, covering sources from both animals and plants. Although Australia is often portrayed as a harsh environment for agriculture (Henzell 2007), its food production systems are extremely diverse. The first phase of this review identified over 50 protein source systems, from mainstream meat production such as beef, lamb, fish, pork and chicken to niche production such as emu, crocodile, camel and pheasant (Foster 2009). Red and white meat protein sources include both introduced domesticated and native animals, whereas the crops that provide or support protein sources are all introduced.

From this considerable array of options, 10 protein sources were selected for a comparative analysis of their impacts on biodiversity. These represent the most commonly produced and consumed protein sources; those that can be considered as alternative consumption purchases to red meat. They can be characterised both in terms of their food classification (red meat, white meat, plant-based and other) and in terms of the intensification of production system. Three levels of production were identified for this review, which in order of intensity from highest to lowest are: high density (industries that keep animals, birds, reptiles, fish or crustaceans in close quarters with predominantly introduced water and feeding as opposed to grazing), intensive (industries where native vegetation has been cleared and converted to another land use, principally exotic pastures or crops that have inputs such as fertiliser and/ or water added) and extensive (industries that utilise native vegetation as the resource base and have relatively low stocking rates) (Table 1).

The research and policy sectors that focus on the conservation and management of biodiversity largely use a threat-based approach to classifying impacts. Because of the lack of a consistent methodology for identifying threats to biodiversity in Australia (Burgman et al. 2007; Coutts-Smith et al. 2007; Auld and Keith 2009), and the need to consider impacts in a broader framework (Röling 2003), the widely adopted pressure-stateresponse (PSR) model developed by the Organisation for Economic Co-operation and Development (OECD 1993) was used in this report. In Australia, the PSR model, and variations on it, are used in State of the Environment reporting by governments at the local, state and national levels (e.g. Beeton et al. 2006). 'Indicators' are the essential components of these models, but data are often lacking to demonstrate trends over time (Williams et al. 2001). For the present study, the PSR model is used for each protein source. Formal indicators were not developed, but where possible, data collected on trends over time are used to illustrate patterns. Often these data come from surrogates of biodiversity, such as the amount of native vegetation cleared.

Ten broad pressures were selected for examination, based on several national and major publications on pressures on biodiversity (e.g. Williams et al. 2001; NLWRA 2002; Beeton et al. 2006). Many of the pressures are common across different protein sources. For example, vegetation clearance and modification is related to the beef, sheep and dairy industries for pasture production and several protein sources that are associated with grain production for both animal and human consumption. The pressures described in this manner, and the industries to which they relate to, are listed in Table 2. If there are particular examples of pressures that are specific to only one or two protein sources, they are covered in the 'Other' category. These include the killing of dingoes to protect livestock, which is largely associated with the sheep industry, and direct reduction of populations from wild catch, such as fisheries. 
Table 1. Intensity of the production system associated with selected sources of protein

\begin{tabular}{|c|c|c|c|}
\hline Protein source & High density & Intensive & Extensive \\
\hline \multicolumn{4}{|c|}{ Red meat } \\
\hline Cattle & Feedlots & High-input pasture & Low-input pasture \\
\hline Sheep & Feedlots & High-input pasture & Low-input pasture \\
\hline Kangaroo & - & - & Native populations \\
\hline Goat & - & High-input pasture & Low-input pasture \\
\hline \multicolumn{4}{|c|}{ White meat } \\
\hline Poultry & Battery & Free range & - \\
\hline Pigs & Feedlots & Free range & - \\
\hline Fish & Aquaculture ${ }^{\mathrm{A}}$ & - & Native populations \\
\hline \multicolumn{4}{|c|}{ Plant-based } \\
\hline Grains, legumes and pulses & - & High-input cropping & - \\
\hline \multicolumn{4}{|c|}{ Other } \\
\hline Eggs & Battery & Free range & - \\
\hline Dairy & Feedlots & High-input pasture & - \\
\hline
\end{tabular}

${ }^{\mathrm{A}}$ Includes both terrestrial and sea-based fish farming.

Table 2. Pressures of biodiversity by different protein sources

\begin{tabular}{ll}
\hline Broad pressure & Protein sources \\
\hline Vegetation clearance and modification & $\begin{array}{c}\text { Beef, sheep and diary industries for pasture production; grain production for intensive enterprises } \\
\text { and feedlots (dairy, cattle, sheep, pigs, chickens); grains and legumes grown for human consumption; } \\
\text { potential minor clearing for pork and chicken high-density facilities }\end{array}$ \\
$\begin{array}{l}\text { Altered fire regimes } \\
\text { Altered grazing regimes }\end{array}$ & Beef, sheep, goats, dairy and kangaroos \\
Altered hydrology & Beef, sheep, diary, pork, chicken, eggs \\
Trampling and compaction & Beef, sheep, dairy, pork \\
Invasive species & Weeds - beef, sheep and dairy; escaped organisms - fisheries \\
Pollution (water, soil and air) & All protein sources, except kangaroos \\
Disease and pathogens & Pork, chickens and eggs, fisheries \\
Climate change & All protein sources, to varying degrees \\
'Other' pressures, including direct decline & Fisheries, kangaroos, sheep (culling of dingoes) \\
of biota from harvesting & \\
\hline
\end{tabular}

The results section of this review reports on the impacts of each protein source against the relevant pressures and includes commentary about industry responses and monitoring.

\section{Literature review}

When taking into consideration the number of protein sources examined, and the diversity of intensification systems associated with each protein source, a total of 20 different production systems was examined for the review (Table 1). The analysis of these diverse systems is based on the contemporary literature covering the pressures on biodiversity, the state (quality and quantity) of biodiversity and the responses of society through environmental, general economic and sectoral policies, and through changes in awareness and behaviour. Both terrestrial and aquatic biodiversity were included in the review. With the scope of this project limited to Australia, most of the literature is of necessity Australian. That said, the scarcity of biodiversity impact studies for many protein sources in Australia, and in particular the high-density industries (e.g. pork, chicken and cattle), has meant reliance on overseas literature where its relevance can be translated to the context of this review.
Over 500 hundred publications were cited in the report that underpins this review paper, with many more considered. Because of the large scope of the review (both geographically and the subjects covered), the time and resources available for the report that underpins the review (Williams and Price 2009), and to avoid re-inventing the wheel, review papers and national reports were used where possible. Precedence was given to peer-reviewed scientific literature or official statistics in the public domain. Some reliance on the 'grey literature', including industry publications and conference papers, was required however. In some instances these publications were the only place where relevant information for the review could be found.

Much of the biodiversity literature in production landscapes has focussed on the patches of native vegetation that remain in the landscape, rather than examining biodiversity as a part of farming systems. This reflects the fledgling interest in studies that aim to integrate biodiversity into agriculture systems (Lowe et al. 2006). Recent programs such as Land, Water \& Wool (Wagg et al. 2007; Williams and Goodacre 2008) and Grain \& Graze (Price and Hacker 2009) are starting to address this area. Examples from these programs are drawn on, where relevant to the review. 


\section{Extent and significance of protein sources}

In $2007-08, \sim 54 \%$ of Australia's total land area was managed by agricultural businesses (ABS 2009) for the production of food, fibre and other products. This equates to $\sim 4.15$ million square kilometres, or 415 million hectares. The management of these extensive areas therefore has a major bearing on biodiversity conservation and management in Australia. Grazing land for domestic cattle, sheep and dairy accounted for $87 \%$ of land managed by agricultural businesses in 2007-08, so they are significant industries both in terms of geographic extent and their contribution to the economy. This included both grazing on improved pasture (16\% of agricultural land use) and other grazing land ( $71 \%$ of agricultural land use). Other agricultural land use included $8 \%$ for cropping, some of which is used to feed animals for meat production, especially in high-density systems. Fig. 1 provides a visual image of the area that the different land uses cover, with native grazing and modified pastures represented by the light cream and tan colours, respectively.

The kangaroos and goats used as protein sources are from wild sources, being native and feral, respectively. They cover large areas of Australia's land area (see sections following for details), principally in semiarid areas, and overlap in geographic distribution with cattle and sheep. High-density feedlots and battery-hen production facilities are mostly found in coastal areas, with a concentration around northern New South Wales (NSW) and south-eastern Queensland for cattle feedlots.

The fisheries analysed in this review cover wild and farmed populations, both marine and freshwater. For the purposes of this review, the industry comprises the commercial sector covering the high seas (generally between 3 and 200 nautical miles from the Australian coast), the coastal zone (within 3 nautical miles) and inland fishing and aquaculture (www.afma.gov.au, verified 5 May 2009). The high-density aquaculture sector has grown rapidly to the point that it now accounts for one-third of the value of the Australian fishing industry (ABARE 2008). Aquaculture is located across all states of Australia.

The key attributes of the protein sources reviewed, including the contribution they make to the Australian economy (gross value of production), are described in Table 3. This table demonstrates the significant contribution made by the beef cattle, cereal, dairy, sheep and seafood industries to the Australian economy, including the employment that is provided in rural areas. With the growing sales of chicken meat in Australia, this industry is making an increasing contribution to the economy. In terms of the total GDP of the Australian economy, agriculture provides $\sim 3 \%$.

\section{Findings}

\section{A precautionary note}

Several challenges were identified during this review, which need to be acknowledged when considering the findings outlined in this paper.

For many industries, drawing a direct link between production systems and actual loss of biodiversity is difficult, if not impossible. Production systems rarely interact with landscapes and ecosystems in isolation from other anthropocentric activity (Woinarski and Ash 2002; Lindenmayer and Fischer 2006). It is

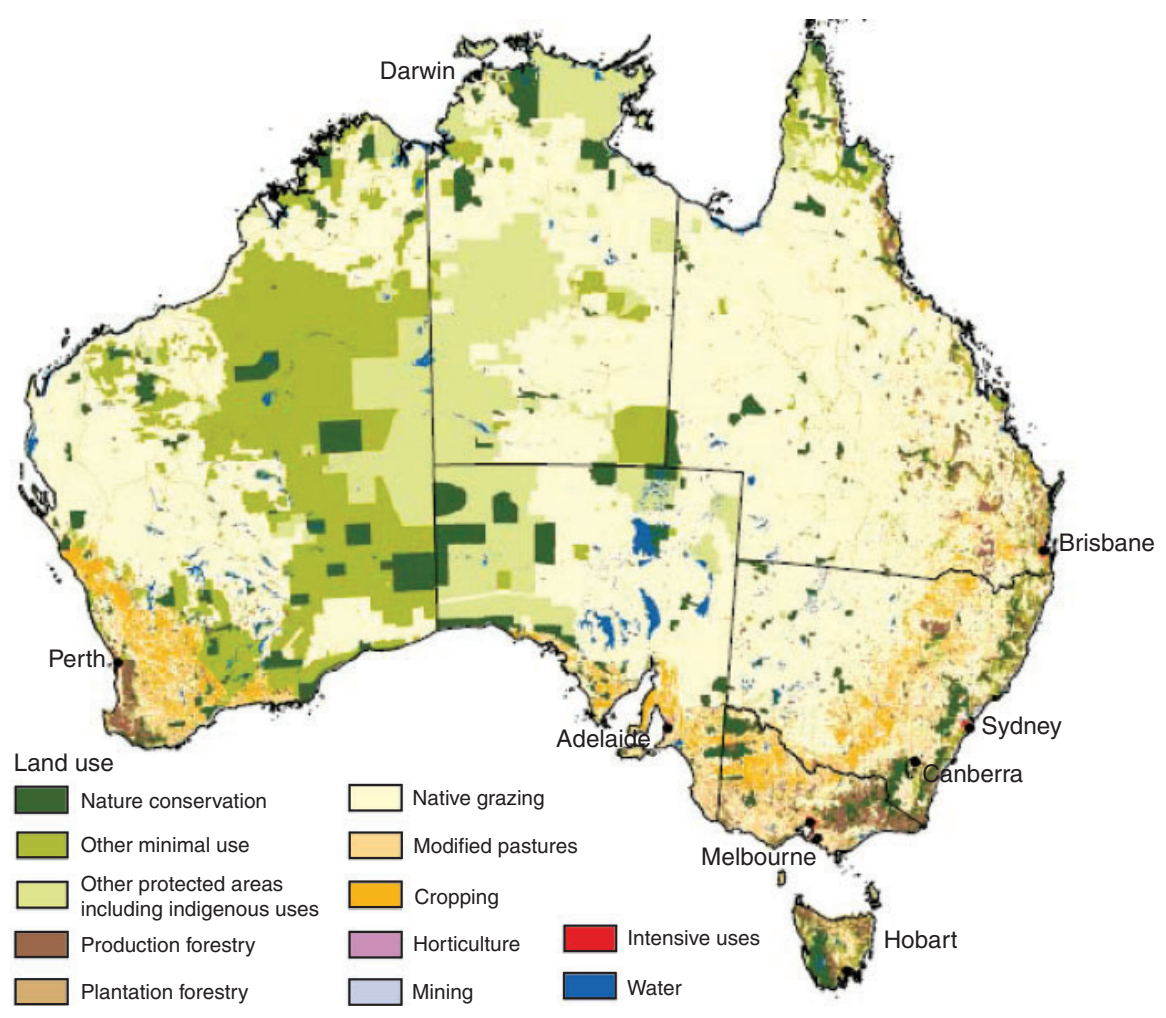

Fig. 1. A 2000-01 national-scale land-use map, illustrating the broad distribution of pastures and crops across Australia (source: National Land and Water Resources Audit 2008). 
Table 3. Key attributes of protein sources (Australian) used in the study

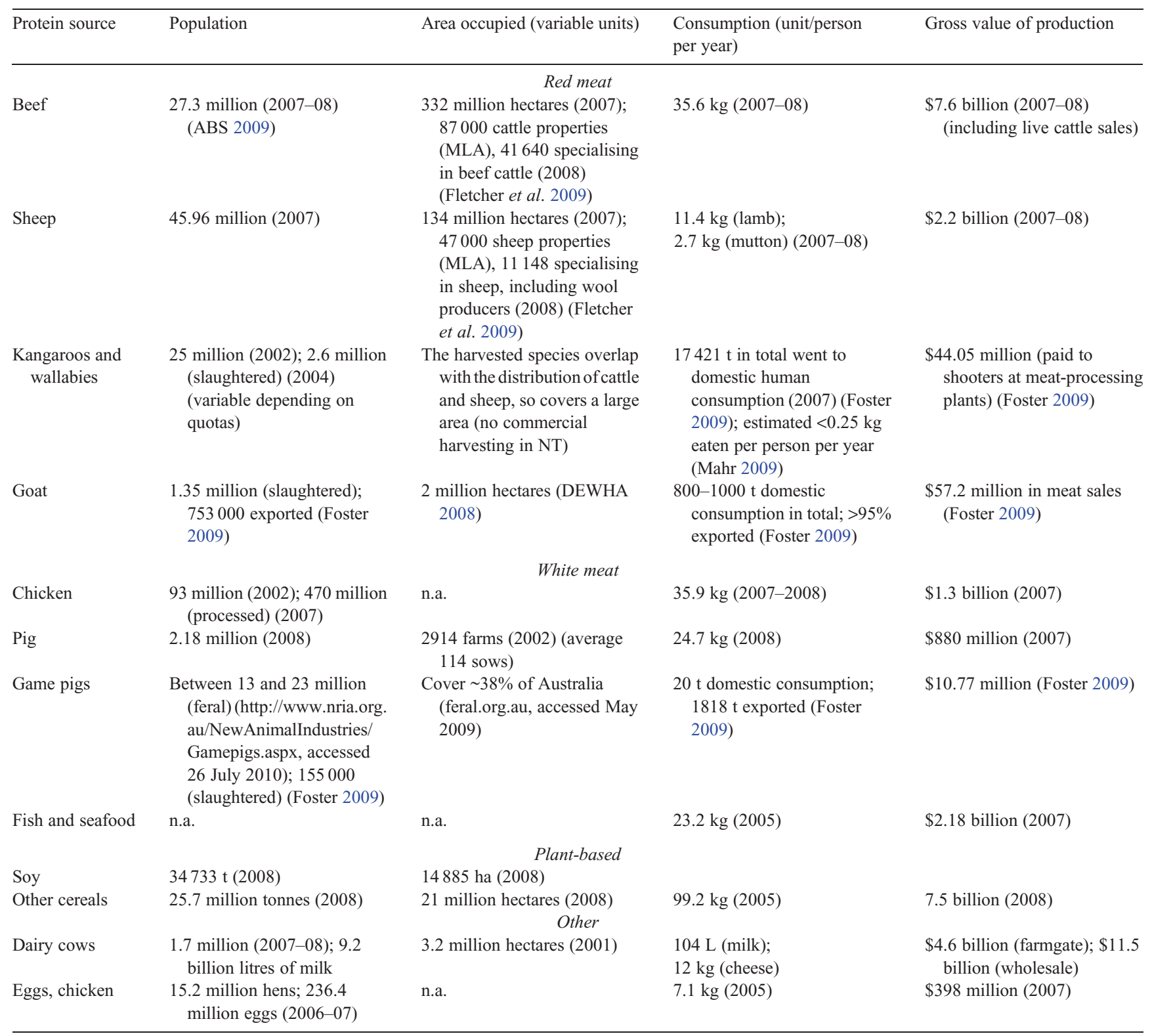

far easier to measure the contribution to a pressure than it is to accurately apportion responsibility for the outcomes of that pressure. In many cases it was difficult to quantify the exact contribution each protein source had made to the pressures on biodiversity, such as attributing the amount of vegetation cleared for cattle and sheep meat production. The interactions between many of the pressures, such as fire and grazing and fertiliser use and grazing, also made it challenging to make direct links between particular pressures and the state of biodiversity. Across Australia, the loss or modification of Aboriginal fire regimes, which is related to European settlement, has had an impact on biodiversity, in addition to pressures associated with pastoralism, for example.
The lack of a standard approach to describing grazing regimes (Lunt 2005) was a constraint on reviewing the pressures associated with altered grazing regimes. The framework developed by Lunt et al. (2007), which is designed to predict the effects of livestock grazing and grazing exclusion on conservation values in natural ecosystems, is limited by the lack of quantitative measures of grazing impact such as stocking rate and documentation of the type of stock involved. The paucity of information on attributes such as these in biodiversity studies has limited the ability to identify direct cause-and-effect relationships. In one sense, it is only in the wild catch industries that we can be more certain about these relationships, although even here, the pressures on 
fish populations come only partly, albeit significantly, from fishing.

Table 4 summarises the potential relative contribution of the 10 different protein sources to various pressures on biodiversity from our review. Relative here refers to potential contribution 'relative' to the other industries studies, and so, for example, a 'high relative contribution' should not be taken to mean 'high impact'. Although Table 4 can be used to make comparisons between industries, the authors urge caution against this as it could have the perverse outcome of giving some industries an unwarranted sense of assent that might result in diverting attention from the collective responsibility for protecting biodiversity and ecosystems. Comparisons may also lead to the impression that those industries with a higher impact are not sustainable or are inadequately responding. The practices of the red meat industry now, for example, differ in many ways from those that lead to the high impact that this industry has had in the past. The wild fisheries industry has also put several measures in place that are addressing the over-fishing of wild stock (Worm et al. 2009). It should also be acknowledged that broad-scale land clearing, which has now markedly declined in Australia, was once in response to public policy that reflected the values of the time (Holmes and Knight 1994; Holmes 2000).

One of the issues to consider when comparing different protein sources is the interplay between the intensity of production, e.g. extensive grazing compared with feedlots, and the area affected. In Australia, Dorrough et al. (2007) addressed this question at the property scale by comparing the impacts of low-input native pastures (extensive systems) to introduced pastures where fertilisers are used (intensive systems). The authors concluded that extensive management, rather than more intensification, may be necessary to maintain biodiversity and prevent further long-term degradation of the resource base (Dorrough et al. 2007). This conclusion was drawn, in part, because extensive systems in Australia often still have a major native pasture component. These findings are relevant to studies from overseas that demonstrate increasing rates of intensification in countries such as New Zealand (e.g. MacLeod and Moller 2006). As these authors note, case studies have linked dramatic declines in biodiversity in farmland in Europe and North America to agricultural intensification. As noted later in the present review, although the value of extensive native systems for biodiversity can be also diminished through factors such as overstocking and weed invasion, these can be addressed through improved management practices.

Critically, readers should note that Table 4 is drawn from the authors' interpretations of the limited studies available. These studies are limited in scope rather than in number. Most of them deal with pressures rather than with actual direct impacts and attribution to these.

\section{Relative contributions to biodiversity pressures}

Overall, the results summarised in Table 4 show that the beef industry has the largest relative potential contribution to the impact on terrestrial biodiversity in Australia by both the area covered and the nature of the impacts. This includes the area of native vegetation cleared for grazing, the amount of grain used in high-density feedlots, and the quantity of greenhouse gases emitted. The dairy industry makes a contribution to beef production, with male cows reared for sale as veal or beef (MLA 2007a, 2007b; Dairy Australia 2009). Although much of the damage in the rangelands and southern Australia is the legacy of past management, as well as pressures associated with the wool industry in the southern rangelands (Fisher et al. 2004), it has left a lasting public impression about the impacts of the cattle and sheep industries on biodiversity (Morton et al. 1995; NLWRA 2002). The potential impacts of feral goats on biodiversity, which are the

Table 4. Potential relative contribution of different protein sources to the pressures on biodiversity

Relative pressure $=$ contribution relative to other protein sources. $\mathrm{H}$, high; $\mathrm{M}$, medium; L, low. ${ }^{\mathrm{O}}$, ocean floor dragging. ${ }^{\mathrm{W}}$, wild catch/harvest. BMP, industry-driven best management practice

\begin{tabular}{|c|c|c|c|c|c|c|c|c|c|c|c|c|}
\hline \multirow{3}{*}{ Protein source } & \multicolumn{10}{|c|}{ Potential relative contribution to pressure on biodiversity } & \multirow{2}{*}{\multicolumn{2}{|c|}{$\begin{array}{c}\text { Response } \\
\text { presence of } \\
\text { intervention }\end{array}$}} \\
\hline & $\begin{array}{l}\text { Vegetation } \\
\text { clearance }\end{array}$ & $\begin{array}{l}\text { Altered } \\
\text { fire }\end{array}$ & $\begin{array}{l}\text { Altered } \\
\text { grazing }\end{array}$ & $\begin{array}{c}\text { Altered } \\
\text { hydrology }\end{array}$ & $\begin{array}{c}\text { Trampling } \\
\text { and }\end{array}$ & $\begin{array}{l}\text { Invasive } \\
\text { species }\end{array}$ & $\begin{array}{l}\text { Pollution } \\
\text { (air, water, }\end{array}$ & $\begin{array}{c}\text { Disease } \\
\text { and }\end{array}$ & $\begin{array}{l}\text { Climate } \\
\text { change }\end{array}$ & $\begin{array}{c}\text { Direct loss } \\
\text { of biota }\end{array}$ & & \\
\hline & & regime & regime & & compaction & & & pathogens & & & Regulation & BMP \\
\hline Beef (ext) & $\mathrm{H}$ & $\mathrm{H}$ & $\mathrm{H}$ & $\mathrm{H}$ & $\mathrm{H}$ & $\mathrm{H}$ & M & $\mathrm{L}$ & $\mathrm{H}$ & $\mathrm{L}$ & M & M \\
\hline Beef (feedlot) & M & $\mathrm{L}$ & M & M & $\mathrm{L}$ & $\mathrm{L}$ & $\mathrm{M}$ & M & M & $\mathrm{L}$ & $\mathrm{H}$ & $\mathrm{H}$ \\
\hline Lamb (ext) & M & M & M & $\mathrm{L}$ & M & M & $\mathrm{L}$ & $\mathrm{L}$ & $\mathrm{L}$ & $\mathrm{L}$ & M & M \\
\hline Lamb (feedlot) & $\mathrm{L}$ & $\mathrm{L}$ & $\mathrm{L}$ & $\mathrm{L}$ & $\mathrm{L}$ & $\mathrm{L}$ & $\mathrm{L}$ & $\mathrm{L}$ & $\mathrm{L}$ & $\mathrm{L}$ & $\mathrm{H}$ & M \\
\hline Goat & $\mathrm{L}$ & $\mathrm{L}$ & M & $\mathrm{L}$ & $\mathrm{L}$ & $\mathrm{L}$ & $\mathrm{L}$ & $\mathrm{L}$ & $\mathrm{L}$ & $\mathrm{L}$ & M & $\mathrm{L}$ \\
\hline Kangaroo & $\mathrm{L}$ & $\mathrm{L}$ & M & $\mathrm{L}$ & $\mathrm{L}$ & $\mathrm{L}$ & $\mathrm{L}$ & $\mathrm{L}$ & $\mathrm{L}$ & $\mathrm{L}$ & M & $\mathrm{M}$ \\
\hline Pork (indoor) & $\mathrm{L}$ & $\mathrm{L}$ & $\mathrm{L}$ & $\mathrm{L}$ & $\mathrm{L}$ & $\mathrm{L}$ & M & M & $\mathrm{L}$ & $\mathrm{L}$ & $\mathrm{H}$ & M \\
\hline Pork (outdoor) & $\mathrm{L}$ & $\mathrm{L}$ & $\mathrm{L}$ & $\mathrm{L}$ & $\mathrm{L}$ & $\mathrm{L}$ & $\mathrm{L}$ & $\mathrm{L}$ & $\mathrm{L}$ & $\mathrm{L}$ & $\mathrm{H}$ & M \\
\hline Chicken (indoor) & $\mathrm{L}$ & $\mathrm{L}$ & $\mathrm{L}$ & $\mathrm{L}$ & $\mathrm{L}$ & $\mathrm{L}$ & M & M & $\mathrm{L}$ & $\mathrm{L}$ & $\mathrm{H}$ & M \\
\hline Chicken (outdoor) & $\mathrm{L}$ & $\mathrm{L}$ & $\mathrm{L}$ & $\mathrm{L}$ & $\mathrm{L}$ & $\mathrm{L}$ & $\mathrm{L}$ & $\mathrm{L}$ & $\mathrm{L}$ & $\mathrm{L}$ & $\mathrm{H}$ & M \\
\hline Fish (wild catch) & $\mathrm{L}$ & $\mathrm{L}$ & $\mathrm{L}$ & $\mathrm{L}$ & $\mathrm{H}^{\mathrm{O}}$ & $\mathrm{L}$ & $\mathrm{L}$ & $\mathrm{L}$ & $\mathrm{L}$ & $\mathrm{H}^{\mathrm{w}}$ & $\mathrm{H}$ & M \\
\hline Fish (aquaculture) & $\mathrm{L}$ & $\mathrm{L}$ & $\mathrm{L}$ & M & $\mathrm{L}$ & M & M & M & $\mathrm{L}$ & $\mathrm{L}$ & $\mathrm{H}$ & $\mathrm{M}$ \\
\hline Plant-based & M & M & $\mathrm{L}$ & $\mathrm{H}$ & M & M & M & $\mathrm{L}$ & $\mathrm{L}$ & $\mathrm{L}$ & M & M \\
\hline Dairy & M & M & M & M & M & M & M & $\mathrm{L}$ & M & $\mathrm{L}$ & $\mathrm{H}$ & $\mathrm{H}$ \\
\hline Eggs (indoor) & $\mathrm{L}$ & $\mathrm{L}$ & $\mathrm{L}$ & $\mathrm{L}$ & $\mathrm{L}$ & $\mathrm{L}$ & M & M & $\mathrm{L}$ & $\mathrm{L}$ & $\mathrm{H}$ & M \\
\hline Eggs (outdoor) & $\mathrm{L}$ & $\mathrm{L}$ & $\mathrm{L}$ & $\mathrm{L}$ & $\mathrm{L}$ & $\mathrm{L}$ & $\mathrm{L}$ & $\mathrm{L}$ & $\mathrm{L}$ & $\mathrm{L}$ & $\mathrm{H}$ & M \\
\hline
\end{tabular}


main source of goat meat for the commercial market, is reflected in the fact that they have been listed as a key threatening process to biodiversity by the Commonwealth Government [Environment Protection and Biodiversity Conservation Act 1999 (Cwlth)]. This is due to the threats feral goats pose to several species and ecosystems. Kangaroos have a limited impact on biodiversity, except in areas where their numbers have increased due to changes in land management such as the availability of exotic pastures.

Australia's plant-based protein production systems contributed to the clearing of native vegetation, preceding the grazing industry in this regard. Chemical runoff and drift is included among the impacts of plant-based production systems on biodiversity.

In terms of aquatic biodiversity, fisheries (wild and farmed) have the major potential relative contribution to impact. The decline in wild fisheries around the world and the subsequent impacts on biodiversity have led to an increasing focus on aquaculture, with Australia producing increasing amounts of salmon and other sought-after products (ABARE 2008). Aquaculture has a wide range of potential impacts on biodiversity (Food and Agriculture Organisation 2008). These include the impact on wild-fish populations that are harvested to provide fish pellets, as well as the impacts of additives to aquaculture pens, the waste they produce and the fish that can escape (Beveridge et al. 1994; Beardmore et al. 1997; Canonico et al. 2005).

Given the strictures of journal papers, a comprehensive outline of the authors' analysis of the contribution of each protein source to the different pressures on biodiversity cannot be provided in detail here. Such analysis appears in the industry report associated with the present study (Williams and Price 2009). A summary of the contributions, however, follows.

\section{Impact of protein production systems on biodiversity}

The following section of the review addresses a range of pressures on biodiversity associated with different protein production systems. Although these pressures are treated separately for the ease of presentation, the often complex interactions among these pressures are recognised and addressed where possible.

\section{Vegetation clearance and modification}

Clearance of vegetation for production purposes in Australia is associated with both the grains industry and for grazing systems where native vegetation is cleared and often sown with introduced pastures (e.g. Graetz 1998; Fairfax and Fensham 2000). On the basis of the information available, the red meat industry, most notably beef, has been the biggest contributor to vegetation clearance for grazing management; however, as previously noted, this was sometimes done at the behest of public policy. In the authors' assessment in Table 4, the relative contribution to land clearing for lamb and mutton is considered moderate, rather than high, as would have been the case for the total sheep industry (which has been dominated by wool production until recently).

Land clearing for grains has also been significant, both for protein production as well as for feed associated with intensive red and white meat production (Fig. 2). Here, and again, land clearing has been the result of past action and policy (Pannell 2005). In

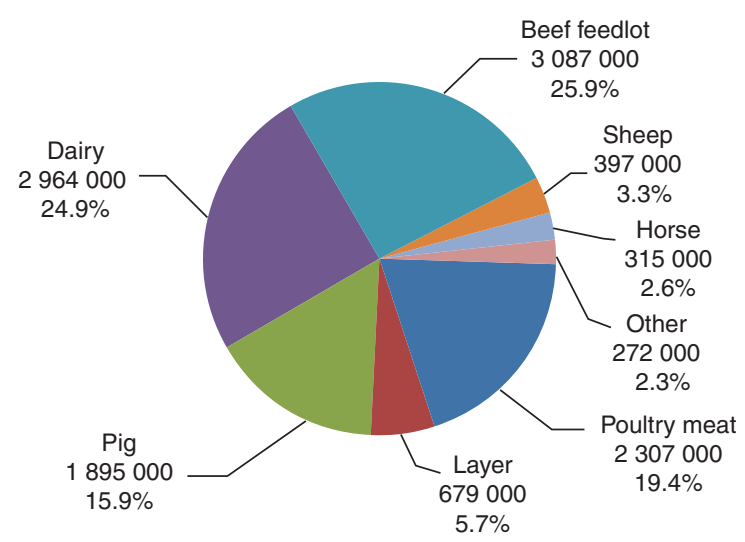

Fig. 2. Feed use by Australian livestock industries in tonnes for the year 2007 (source: Spragg 2008). Units are million metric tonnes.

recent years, the total land dedicated to cropping has reached a plateau (ABARE 2007b). To the extent that Australia can minimise its imports of grain feed and growers have control over their responses, the environmental footprint of these industries can be contained and more easily improved.

Broad-scale clearing of native vegetation for agriculture (cropping and grazing) has been identified as the most serious pressure affecting biodiversity in Australia (Glanznig 1995; Morgan 2001; Williams et al. 2001; NLWRA 2002) because of the range of impacts associated with it. The majority of clearing in Australia has occurred in southern and eastern Australia, with the south-west of the continent being particularly affected. Of an estimated total cover of over 24.693 million hectares in southwestern Australia, 20.1 million ha have been cleared (George et al. 1996). In the period 1945-1995, as much land was cleared as in the 150 years before 1945. Data reported in Graetz (1998) suggest that early clearing of native vegetation in Australia was principally for cropping; with clearing for pastures increasing in importance from the 1950s on. These data indicate that annual rates of clearing peaked in the 1970s, when extensive areas were cleared in south-western Western Australia and Queensland for grain production and in Queensland to increase the area of sown pastures. In the past decade or so, the highest rates of broad-scale clearing of native vegetation was recorded in inland Queensland (Williams et al. 2001), which was primarily related to the cattle industry.

Fig. 3 illustrates that although the total area of land cleared (green bars) in Australia has declined between 1973 and 2004, there are millions of hectares of native vegetation that have been replaced by other land uses over this 30-year period. Recent commentary suggests that new pressures are starting to eclipse clearance of vegetation in terms of their impacts, such as climate change and water extraction (Beeton et al. 2006; Burgman et al. 2007). Although overall rates of clearing appear to be declining (Fig. 3), the legacy of past clearing and ongoing clearance - both broad-scale and through less obvious mechanisms such as lack of regeneration due to grazing (Williams et al. 2001; Fischer et al. 2009) - still represents a major pressure on biodiversity.

There are multiple direct impacts of broad-scale vegetation clearance and modification on biodiversity, as indicated in Table 2. These include death of native animals through loss of 


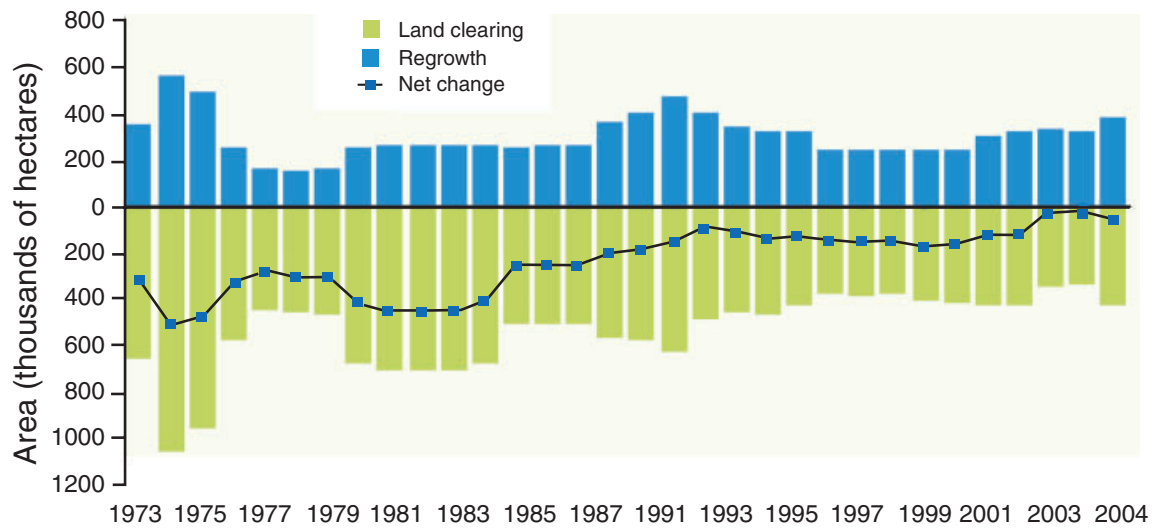

Fig. 3. Net forest change in Australia (using forest regrowth and deforestation data) 1973-2004 (source: Beeton et al. 2006).

habitat and during clearing activities, loss of deep-rooted perennial trees and shrubs, increased habitat fragmentation, leaving small patches, scattered trees and reduced connectivity, reduced ground cover, reduced canopy cover (and altered micro-climates), potential for increased invasion of environmental weeds, increased soil compaction and greenhouse gas emissions (contributing to climate change) and reduced riparian vegetation. These direct impacts can have flow-on effects that can also negatively affect biodiversity, such as potential changes in regional climate due to the broadscale conversion of native vegetation (e.g. Deo et al. 2009) and increased soil salinity concentration and erosion events that can impact on aquatic ecosystems (Williams and Price 2009).

One of the indirect impacts of clearing for agriculture has been the changes in the populations of kangaroos and other native animals in response to the increased availability of productive pastures and crops, the decreased availability of habitat, and in some areas the decreased predation by dingoes and increased access to water (McAlpine et al. 1999). In some cases, this has put pressure on the native systems that remain, when kangaroo and wallaby numbers exceed their carrying capacity (Viggers and Hearn 2005; Norton and Johannsohn 2010).

Clearing of native vegetation is associated with habitat fragmentation, which leaves a legacy of different patch sizes and connectivity, as well as an ongoing decline in vegetation condition due to pressures such as overgrazing and in some cases fertiliser use. Publications such as Gibbons et al. (2006) and Lindenmayer and Hobbs (2007) provide a useful overview of some of the issues related to the fragmentation of native vegetation and attempts to understand and measure vegetation condition.

\section{Altered grazing regimes}

\section{Setting the context}

In Australia, grazing land for domestic cattle, sheep and dairy accounted for $87 \%$ of land managed by agricultural businesses in 2008 (ABS 2009) or 361 million hectares. This included both grazing on improved pasture (16\% of agricultural land use) and other grazing land ( $71 \%$ of agricultural land use). Fig. 1 shows that sheep grazing is restricted to southern and eastern Australia, whereas cattle extend into northern and central Australia, being found in most regions. A continent-wide analysis of total grazing pressure (TGP) in relation to net primary productivity (NPP) undertaken for the 2006 State of the Environment (SoE) report compared the grazing pressure of sheep, cattle and kangaroos, based on an estimated kangaroo population of 19 million (Beeton et al. 2006). The study found that cattle contributed $66 \%$ of TGP, sheep $30 \%$ and kangaroos $4 \%$. The report estimated that areas of low NPP and high dry sheep equivalent (DSE) (Table 5) $\left(\sim 20649 \mathrm{~km}^{2}\right)$ were most at risk from grazing pressure. Even though the analysis was called an interpretation, with the approach used containing several caveats, it gives an indication of the potential contribution of different herbivores to grazing pressure at a national scale.

Of the different industries, beef production makes the most significant contribution to altered grazing regimes and the associated pressures on biodiversity in Australia. This is similar to patterns across the globe (Steinfeld et al. 2006, 2010), due to the extensive nature of production of much of the beef industry. Asner et al. (2004), in a review of grazing systems and global change, noted that managed grazing lands occupy $25 \%$ of the global land surface, with the area increasing six-fold between 1700 and 1990. They contend that even though managed grazing is a spatially diffuse land use and less intensive than cropping, globally it is a major driver of deforestation, woody encroachment and desertification. Even cattle in feedlots graze in either intensive or extensive systems at some point in their life cycle (Owens et al. 1995). The lamb, dairy and goat industries in Australia also contribute to grazing pressure to lesser degrees.

Grazing ecology must be treated as a complex field. This is illustrated in Box 1, which provides examples of the factors that influence grazing patterns and associated pressures. It is important to be able to describe the grazing regime (season, intensity and frequency), as well as the type of herbivores involved, when examining grazing pressures on biodiversity. The absence of a standardised method for describing grazing regimes in grazing studies has greatly constrained attempts to develop a general understanding of grazing impacts on vegetation. This can make it challenging to tease apart the numerous studies that examine the state of biodiversity grazed 
Table 5. Geographic patterns in grazing impact studies across Australia

\begin{tabular}{|c|c|c|}
\hline Region & Characteristics of the region & $\begin{array}{l}\text { Examples of scientists who have worked on } \\
\text { grazing impacts }\end{array}$ \\
\hline SE Australia & $\begin{array}{l}\text { Highly cleared, leaving remnants and scattered trees, } \\
\text { minimal regeneration of eucalypts. Some native } \\
\text { pastures. Grazing of sheep and cattle. }\end{array}$ & $\begin{array}{l}\text { Lunt, Kirkpatrick, Dorrough, Fischer, Reid, } \\
\text { McIntyre, Clarke }\end{array}$ \\
\hline SW Western Australia & $\begin{array}{l}\text { Highly cleared, leaving remnants and scattered trees, } \\
\text { minimal regeneration of eucalypts. No native pastures. }\end{array}$ & Yates, Ausberg-Train, Hobbs \\
\hline Tropical savannas & $\begin{array}{l}\text { Vegetation largely intact, but modified by environmental } \\
\text { weeds that have an impact on fire regimes. Cattle } \\
\text { grazing. }\end{array}$ & Woinarski, Garnett, Fisher, Ash \\
\hline Semiarid rangelands, central Australia & $\begin{array}{l}\text { Vegetation largely intact, but modified by environmental } \\
\text { weeds that have an impact on fire regimes. Cattle } \\
\text { grazing. Artificial waterpoints widespread. }\end{array}$ & $\begin{array}{l}\text { Landsberg et al., Tiver, Ludwig, Pringle, } \\
\text { James }\end{array}$ \\
\hline Semiarid rangelands, Western Australia & $\begin{array}{l}\text { Vegetation largely intact. Cattle largely in the north, sheep } \\
\text { in south. Artificial waterpoints widespread. Weeds } \\
\text { influence fire regimes. Goats part of grazing pressure. }\end{array}$ & Watson, Hopkins \\
\hline Subtropical grassy woodlands & $\begin{array}{l}\text { Some clearing, but vegetation largely intact. Variegated } \\
\text { landscape. Mainly cattle grazing. }\end{array}$ & McIntyre, McIvor, House, Chilcott, Martin \\
\hline
\end{tabular}

\title{
Box 1. Factors that can affect the pressures that grazing regimes have on biodiversity
}

\begin{abstract}
Different grazing patterns and dietary preferences.
Different herbivores graze differently, have different dietary preferences, are different sizes and have different behavioural and social patterns (Baumont et al. 2000). Cattle, for example, eat plants using their tongues, sheep eat plant parts with their teeth and goats generally browse rather than graze. Different sheep breeds also demonstrate different grazing patterns, with the Dorper breed (used for sheep meat) being less selective than merinos (Brand 2000). Goats have the unique ability to utilise forage resources that cannot be utilised effectively by other ungulates such as sheep or cattle (e.g. thorny plants and species containing high proportions of phenolic compounds (Nastis 1995)). Their biology also allows them to access parts of plants and the landscape that other introduced domestic herbivores are unable to reach.

The palatability of plants to herbivores.

This factor varies significantly, with factors such as the succulence, amount of protein, sugars and fats, and digestibility being important (Valentine 2001). These and other factors influence the impact of different herbivores on natural ecosystems and addressing them can increase our understanding of these complex systems (Hunt et al. 2007). To try to standardise the impact of different herbivores, the dry sheep equivalent (DSE) is a unit frequently used to compare the feed requirements of different classes of stock or to assess the carrying capacity and potential productivity of a given farm or area of grazing land. There is some variation in the weight of a dry sheep used in defining a DSE, which usually is about the amount of feed required by a 45-50-kg wether or nonlactating, non-pregnant ewe to maintain its weight (McLaren 1997).

The landscape context and vegetation type being grazed.

Certain parts of the landscape, such as riparian zones, are particularly susceptible to grazing pressures (Jansen and Robertson 2001; Staton and O'Sullivan 2006). Different plants and ecosystems also respond to grazing differently, with some being very sensitive to grazing by domestic stock and others less so (Lunt et al.2007). In contrast, systems such as Mitchell grasslands in inland NSW and Queensland appear relatively resilient to grazing and other land uses.
\end{abstract}

by domestic stock. In some cases, however, where only one livestock species is involved, such as cattle in northern Australia, the impacts are easier to attribute to grazing. The following text should be considered with these caveats in mind.

At the site scale, Lunt (2005), in a study on grazing impacts on temperate grasslands in Australia, described three major ways grazing animals directly affect natural ecosystems: grazing animals eat plant parts, thereby directly removing vegetation and altering ecological processes within remaining vegetation; the feet of grazing animals directly affect soils, by breaking soil surface crusts, compacting soils and encouraging erosion; and animal wastes (urine, faeces and carcasses) redistribute nutrients within ecosystems. Transporting grazing animals can also transport weed seed.

These processes are not independent, interact considerably and vary in their scale. For example, the build up of nutrients from animals such as sheep is localised, but can have a significant impact on native plant species where it occurs. Increases to soil nitrogen and phosphorus concentrations in these sites strongly affect plant composition and promote exotic species over native species (Prober et al. 2002). Soil changes caused by the feet of grazing animals affect subsequent plant growth, and reductions in plant cover by herbivory affect soils, as witnessed by scalds and erosion (Lunt 2005). 
The nature of the impacts will vary depending on the grazing regime and vegetation type being examined. Grazing also alters the amount of biomass on a site, which in turn has an impact on fire regimes (see next section). In semiarid and rangeland systems, artificial watering points, which are used to spread grazing pressure, can have a major impact on biodiversity (James et al. 1999; Howes and McAlpine 2008). In the present paper, artificial watering points are covered under the pressure 'altered hydrology', demonstrating the connections between different pressures.

In addition to the factors identified in Box 1 being important to consider, the effects of grazing on diversity are scale-dependent, with different outcomes observed depending on the scale that is investigated (Lunt 2005). For instance, herbivores may increase diversity at the small-scale (by reducing competition or providing niches for regeneration) but might reduce diversity at larger scales by selectively depleting species that are sensitive to grazing (Landsberg et al. 2002).

The numerous studies on grazing regime impacts in Australia cluster into geographic areas, which correspond to different vegetation types, histories of land use, current management regimes and where researchers are based (Table 5). For example, in semiarid Queensland, the native overstorey has commonly been cleared and exotic pastures such as buffel grass introduced (Fairfax and Fensham 2000). The geographic areas identified in Table 5 were used to summarise the impact of grazing on biodiversity in Australia. Fisher et al. (2004) developed a comprehensive description of grazing-land management zones for the rangelands, which takes this concept further. Depending on the geographic area, vegetation may have been cleared for pastures or cropping, or pastoral grasses may have been introduced, often becoming environmental weeds. This variation in regional characteristics has an impact on the conclusions drawn from grazing studies, and on how easily they can be generalised.

Overarching the pressures associated with grazing regimes, and the different pressures that interact with them, is the overriding driver of climate and seasonal events on the condition, productivity and sustainability of grazing lands in Australia. From a production perspective, McKeon et al. (2004) described eight major degradation and recovery episodes in the Australian rangelands due to grazing pressure and its interaction with climate, particularly extended low-rainfall events.

When reading the following section, which reviews the impact of grazing regimes on biodiversity, it is important to consider the findings in the broader context outlined here.

\section{Direct impacts of altered grazing regimes}

The following section describes the direct impacts of altered grazing regimes across different geographic areas (Table 6). As described earlier, extensive cattle grazing occurs across the savanna landscapes of northern Australia. Whereas the extinction of medium weight-range mammals in the arid zone is well known (Dickman 2007), the savanna landscapes are still regularly referred to as 'pristine'. This is far from the case. Recent research has shown declines in both birds and mammals across northern Australia, as well as changes in landscape function in response to these and other changes (Franklin et al. 2005; Woinarski et al. 2005, 2007). These changes have been attributed
Table 6. Waste from high-density feedlots production (Queensland) Source: Environmental Protection Agency (Qld) 2001

\begin{tabular}{lc}
\hline Feedlot industry & Waste (t/year) \\
\hline Cattle & 395000 \\
Pig & 19000 \\
Poultry & 202000 \\
Dairy & 5300 \\
Mushroom & 11000 \\
\hline
\end{tabular}

to factors such as the breakdown of traditional Aboriginal land management and the concurrent impacts of altered fire and grazing regimes, changes to water availability and flow and the presence of feral animals and weeds (Woinarski and Ash 2002). Considering the relatively recent nature of studies examining the impact of widespread cattle grazing in northern Australia, especially for fauna, there is some concern amongst ecologists that species may have already been lost from these systems (Woinarski and Ash 2002). As a consequence, differences between sites with contrasting management histories may be more muted.

Trying to tease out the role of grazing impacts from other pressures in these systems can be challenging. As they are part of the overall system being studied, they are perhaps better treated as a 'threat-syndrome' (sensu Burgman et al. 2007), although characterising the relative contribution of different pressures can be useful. Kutt and Woinarski (2007), for example, found a variable response to fire and grazing treatments amongst vertebrate groups. Birds responded more to fire effects (nine species - some declining and some increasing at burnt sites), reptiles to grazing effects (six species - five of these demonstrating a decline in grazed sites) and mammals to the interaction (two species). Five bird species also responded to the interactive effect of fire and grazing. The study demonstrated that although both fire and grazing alone can change the vegetation structure and relative vertebrate species abundance, there was an important interacting influence. Legge et al. (2008) suggest that the interaction between fire and grazing may have been underestimated in the past, given the results of a post-fire study in the Kimberly region.

In trying to address the limited knowledge of the response of fauna to grazing regimes in savanna systems, Woinarski and Ash (2002) described complex responses of frogs, birds, mammals and reptiles in northern Queensland to land use and landscape position. The study was located on military lands, where grazing had been removed for over 30 years after a history of 100 years of grazing. Many individual bird species showed significant responses to land-use type, with bird species composition being significantly related to both land-use type and landscape position. The richness of the mammal fauna was weakly related to landscape position and not related to land-use type. A few individual mammal species showed significant responses to landscape position and land-use type, but mammal species composition was significantly (albeit weakly) related only to land-use type.

Woinarski and Ash (2002) acknowledged some of the sampling constraints in the study, but concluded that the faunal responses were strong enough to attribute, at least 
partially, the broad-scale changes in biodiversity recently recognised across northern Australia to pastoralism. This land use was considered to lead to a substantial rearrangement of the vertebrate fauna, particularly so for reptiles and those mammals and birds associated with the ground and understorey layers (Woinarski and Ash 2002). Five years later, Kutt and Woinarski (2007) found a more subdued response of bird species to grazing impacts on their own, with only one species being more abundant in ungrazed sites. Both studies demonstrated the importance of understanding the habitat and food requirements of individual species to predict the impacts of different management regimes, as well as the complexity of the systems being studied.

An experimental approach has been taken in a study on the impacts of intensifying pastoralism in northern Australia (Fisher et al. 2006). Several grazing treatments are being examined in large-scale plots, with a range biodiversity attributes assessed annually at each site. These include vascular plants, birds, reptiles, small mammals and ants, as well as vegetation structure, ground-layer cover and grazing pressure (Fisher et al. 2006). No effects of the grazing treatments on the sampled biota have emerged after 2 years, which is not unexpected. The black-soil systems being studied are considered to be relatively resilient, and grazing effects must emerge from a background of previous grazing patterns and substantial inter-annual variation (Fisher et al. 2006). The authors therefore emphasise that trials such as this need to be measured over meaningful timeframes (5-10 years) and that it will be important to track to the response of individual species to reflect any significant changes in species composition.

Semiarid Queensland is another region where there is a unique combination of vegetation type, land-use history and grazing management practices. Tree clearing is widespread in these systems, as is the utilisation of exotic pasture grasses (Fairfax and Fensham 2000). Some of the impacts of grazing in these systems were covered in the section on vegetation clearance, as the two often interact. In southern Australia, systems where cattle grazing impacts have been studied include alpine environments, where summer grazing of cattle was practiced for many decades until recently. Wahren et al. (1994), in an analysis of long-term vegetation plots where cattle had been excluded for up to 50 years, identified several grazing impacts on vegetation dynamics. In the longest-grazed plots, this included a decline in regeneration of several plant species and increased bare ground and loose litter. The responses to grazing varied depending on the vegetation type being studied and the fire history of the sites. The publication on alpine grazing that has received the most recent attention, is the one that tests and refutes the hypothesis that 'grazing prevents blazing' by Williams et al. (2006).

Cattle graze forest and woodland ecosystems in north-eastern NSW as a supplement to farmland grazing. Tasker and Bradstock (2006) studied the impacts of the presence and absence of cattle grazing on forest understorey in these ecosystems where it is a widespread practice. They compared it with time since logging and wildfire, which are other management practices in the region. In the context of that study, 'cattle grazing practices' included frequent low-intensity fires that were used by farmers to encourage new growth. Stocking rates were low, with one animal for every 4-20 ha, depending on the vegetation type (Tasker and
Bradstock 2006). The authors found that grazed (and burnt) sites had significantly lower vegetation complexity, different dominant understorey species, reduced or absent shrub layers and an open, simplified and more grassy understorey structure than did ungrazed sites. Even though it was not possible to separate the effects of grazing and low-intensity fire, it was considered important to quantify the collective effects of the practices as they are carried out in the real world.

Working on cattle properties in the grazing landscapes of south-eastern Queensland, Martin and McIntyre (2007) reported that provided trees are not cleared, a rich and abundant bird fauna can coexist with moderate levels of grazing. Habitats with high levels of grazing were found to result in a species-poor bird assemblage, dominated by birds that are increasing in abundance nationally. Despite having similar bird assemblages, the effect of grazing was reported to be stronger in riparian habitat than in the adjacent woodland habitat. In the context of the study of Martin and McIntyre, grazing intensity (low, medium and high) was characterised by the intactness of grass swards and whether grazing was selective or non-selective. This was based on previous studies that found that sward structure and composition in these systems are an indicator of grazing history (McIntyre et al. 2003; McIvor et al. 2005).

Although only a small section of the landscape, riparian areas are of great importance as habitat for native species, given the higher water and nutrient availability in these areas. These characteristics generally make riparian areas very productive and, thus, also highly valued for grazing. Riparian systems are particularly susceptible to the impacts of certain grazing regimes, through a combination of both grazing and trampling effects. These impacts can negatively affect vegetation, soil characteristics, water quality, hydrology and the physical characteristics of streams (Jansen et al. 2007a). The susceptibility of riparian zones to grazing was demonstrated by Martin and McIntyre (2007), who found that the impact of cattle on riparian vegetation in south-eastern Queensland was greater on bird species than woodlands close by. In a major study of grazing impacts along the Murrumbidgee River, three-quarters of the variation in vegetation condition was explained by the following five factors: stocking rate, distance upstream, relative periods of paddock rest and grazing, proportion of bank accessible to stock, and the presence of off-river water in the paddock (Jansen and Robertson 2001). These findings were based on a rapid appraisal index for assessing the ecological condition of riparian zones, which has since been widely adapted (Jansen et al. 2007b). Management recommendations based on these results included reduced stocking rates, more off-river watering points and resting of paddocks.

In a related study on wetlands associated with the Murrumbidgee River, Jansen and Healey (2003) studied the impact of livestock grazing on the availability of habitat for frogs in wetlands. Using a sample size of 26 wetlands, the study found that frog communities, species richness and some individual species of frogs declined with increased grazing intensity. Robertson and Rowling (2000), working in the same region, found marked differences in riparian sites with and without livestock. Grazed sites were found to have much lower levels of eucalypt regeneration, different plant-species composition and less coarse particulate organic matter and 
terrestrial fine woody debris. Research such as that of Robertson and Rowling (2000) forms the basis of management guidelines for stock and waterways, such as given in Staton and O'Sullivan (2006).

The way grazing regimes affect biodiversity is a question encompassing the full complexity of ecosystems, especially when interacting pressures are involved. The diversity of studies on cattle grazing regimes across a range of different management histories, vegetation types and interacting factors mostly demonstrate changes in the diversity, distribution and/or composition of native plants and animals. Apart from drawing out broad generalisations from these studies, such as the importance of stocking rate, site condition and management history to how biodiversity responds, teasing apart the subtleties of the impacts and interactions on the state of biodiversity is beyond the scope of the present review.

\section{Altered fire regimes}

The main potential relative contributor to altered fire regimes, and the consequences of this for the composition, abundance and distribution of native species across large tracks of Australian land, has been the extensive red meat industry. Burning of stubble also takes place in some grain production systems, although this has declined since the rapid adoption of conservation tillage practices (Valzano et al. 1997). These pressures interact with other changes to fire regimes caused by altered Aboriginal burning patterns and changes related to the protection of life and property in built up areas. Other protein sources considered in the present review have a less significant impact in respect to altered fire regimes.

Australian ecosystems have evolved with fire. Fire regimes (season, intensity, frequency and type) show considerable variability across different ecosystems (Gill 1975; Whelan 1995; Anon. 1996; Gill et al. 1999; Bradstock et al. 2002; Abbott and Burrows 2003). Indigenous Australians used fire extensively as a management tool(Latz 1995; Dyer et al. 2001). With the permanent settlement of Europeans in Australia, fire regimes changed markedly, with major consequences for biodiversity (Bradstock et al. 2002). This included changes to the composition, abundance and distribution of species, as well as to ecological processes such as competition and pollination (Gill 1975; Bradstock et al. 2002). Depending on the timing of rainfall in relation to areas being burnt, altered fire regimes can exacerbate erosion associated with vegetation clearance and overgrazing (Beeton et al. 2006).

The main pressure caused by cattle, sheep and goats on biodiversity associated with altered fire regimes is through changes to the vegetation dynamics through grazing, trampling and weed invasion, all of which affect the type and distribution of fuel. Changes to fuel characteristics include removal of plant biomass as a result of clearing and overgrazing and changes in fuel type and distribution with the spread of exotic pasture plants such as buffel grass (Butler and Fairfax 2003; Friedel et al. 2006) and gamba grass (Douglas and Setterfield 2005) into natural systems. Fire is also used as a tool by graziers to encourage new growth for cattle and sheep (Dyer et al. 2001; Kirkpatrick and Bridle 2007). Given the extent of grazing lands across Australia, the impacts of red meat production on fire regimes are widespread and cover many ecosystem types. The interactions between fire and grazing, and the potential synergistic effect on biodiversity, are increasingly being studied in the context of pastoral systems (Kutt and Woinarski 2007; Sarah Legge, AWC, pers. comm.).

\section{Altered hydrology}

All agricultural production has an impact on hydrology in one way or another, although the present review found that beef (extensive and intensive), together with the plant-based protein production systems, have the greatest impact. The intensive industries are also shown to have some impact on hydrology, particularly through their high water extraction. However, as a proportion of total water use in agriculture, this remains relatively small (ABS 2006).

Altered hydrology has been listed as a pressure associated with a range of protein sources (Table 2) because of its impact on both aquatic and terrestrial biodiversity. There are two major management activities that directly affect water availability the use of artificial watering points in arid and semiarid systems and changes to environmental flows associated with the use of water for irrigation of pastures or for high-density feedlots (stock and grain production). The provision of artificial watering points makes more grazing land available to stock, with subsequent impacts on biodiversity (Landsberg et al. 1997; James et al. 1999; Fensham and Fairfax 2008; Howes and McAlpine 2008). These studies have shown that although there are no universal patterns that can be described, some native species benefit from the introduction of additional watering points but more are negatively affected. The change in hydrology associated with the removal of deep-rooted woody species is briefly covered in the section on vegetation clearance.

Artificial watering points use water that is drawn from groundwater systems, often causing negative impacts on groundwater-dependent systems such as artesian mound springs (Noble et al. 1998; Ponder 2002; Habermehl 2006). The NSW Scientific Committee that determines the listing of threatened species and communities identified major threats to artesian spring communities related to altered grazing regimes (NSW Scientific Committee 2009a). These included the alteration of flow or unsustainable extraction of water from artesian bores reducing flows to the mound springs and trampling and grazing by stock and feral animals such as pigs, goats and rabbits. The Committee noted that several springs have dried in NSW in the past 100 years due to falling water pressure caused by over-extraction, which has likely caused the extinction of undescribed species of aquatic invertebrates. Because of the pressures caused by pastoralism and feral herbivores, artesian spring communities have also been listed as an endangered ecological community at the national level by the Commonwealth government.

The impact of human activities on environmental flows has received considerable attention across the research and policy community (e.g. the Living Murray Initiative (Murray-Darling Basin Commission 2008), the National Sustainable Irrigation Program (NPSI 2009), various environmental flow research programs). Irrigation for pastures and crops uses water that would have originally flowed into the environment. Dairy 
farms in northern Victoria/southern NSW use $60 \%$ of the irrigation supply and thus contribute to environmental issues such as environmental flows in rivers and rising watertables, with the associated impacts on salinity (Ho et al. 2004). In northwestern Tasmania, dairy farmers have changed the drainage of their properties to increase access to what was originally low-lying blackwood swamp-land. As a result, much of the Montague River, and its tributaries, has been highly modified or straightened (DPIW 2009). The potential impact of such management practices on groundwater is just starting to be examined (Holz 2009). More broadly, the impact of reduced environmental flows on biodiversity has received considerable attention (Richter et al. 1997; Kingsford 2000; Arthington et al. 2006).

The use of the 'virtual water' is one approach used to assess water use by different food production systems. The value of this and other approaches as comparative tools are covered in Wiedemann et al. (2009), a companion study to the present review, focusing on the impact of different protein sources on water use and contribution to greenhouse gasses.

\section{Trampling and soil compaction}

Most protein sources covered in the present review potentially contribute to the pressures associated with trampling and soil compaction. As is to be expected, however, the extensive hoofed animal industries (beef and lamb/mutton) and heavy machinerydependent industries (plants) are the major contributors. The fishing industry is also a significant contributor through damage to ocean-floor habitats through 'trampling-like' activities such as dragging nets, dredges and rakes along the sea bed (Auster and Langton 1999).

The impacts of trampling and soil compaction are treated separately from altered grazing regimes because the impact of hard-hoofed herbivores on the soil and vegetation systems of Australia is one of considerable interest and commentary. Hacker and McLeod (2003) contended that under appropriate managements, the type of hooves a grazing animal has is not relevant. These authors attributed damage to soil to overstocking and poor rangeland management. This could be tested by comparing the impact of different management regimes on soil and vegetation characteristics, especially where stock are matched to land capability. The holistic management approach to grazing, developed by Alan Savory based on his experience in South Africa, uses trampling by stock as a tool to manage landscapes, aiming for the stock to eat one-third of the plant, trample one-third and leave one-third to regenerate (Savory and Butterfield 1999). These examples demonstrate that as with the direct grazing impacts on native vegetation, the impacts of trampling and compaction on soil ecosystems need to be described in the context of grazing regimes.

Studies such as James et al. (1999), Woinarski and Ash (2002), Duncan et al. (2007) and Howes and McAlpine (2008) have demonstrated that certain grazing regimes can cause long-term damage to soil biota. For example, in a review of the effects of watering points in the arid zone on biota, James et al. (1999) noted that heavy traffic by stock breaks up the cryptogamic crust, which has two consequences: (1) the nitrogen-fixing action of the cryptogams is disrupted and (2) the soil surface is loosened allowing wind and water erosion to remove surface layers. The authors continue, stating that although the compaction of the soil surface due to stock traffic is well documented for non-arid regions, there remains little evidence of widespread compaction in the semiarid rangelands (James et al. 1999), with most impacts being restricted along watering points and along tracks. Eldridge's (1996) work on cryptogamic crusts is cited as an important source for these statements.

In more recent studies, it has been demonstrated that livestock tracks around watering points intensify the natural drainage patterns and exacerbate the natural erosion process (Pringle and Landsberg 2004). Howes and McAlpine (2008), in a review of the impact of arid-zone watering points on biodiversity, found that soil erosion increases significantly within the first $2-3 \mathrm{~km}$ from water as a result of heavy traffic and vegetation stripping, leading to a decline in abundance and richness of palatable forage species.

Yates et al. (2000) cited several studies to support the statement that
'in Australian rangelands the removal of perennial vegetation cover by livestock grazing and trampling by hard hooves is known to cause loss of litter cover, loss of soil cryptogams, reduced organic carbon, loss of nutrients, loss of soil micro-topography, soil compaction, reduced soil water infiltration rates, increased soil surface erosion and consequently loss of ecosystem functions which capture and cycle scarce limiting resources such as water and nutrients'.

This commentary set the scene for their study, which examined the impact of sheep grazing on the soil characteristics of fragmented woodlands in south-western Western Australia. The study of Yates et al. (2000), which compared a range of properties at grazed and ungrazed sites, found major differences in soil and vegetation characteristics. This included a decline in native perennial cover and an increase in exotic annual cover, reduced litter cover, reduced soil cryptogam cover, loss of surface-soil microtopography, increased erosion, changes in the concentrations of soil nutrients, degradation of surface-soil structure, reduced soil water infiltration rates and changes in near-ground and soil microclimate (Yates et al. 2000). Many of these changes are attributable to the hoof action of sheep.

In addition to the variation in impacts of trampling and soil compaction related to stocking rate, certain ecosystems are differentially affected. Riparian areas are particularly susceptible (Jansen and Robertson 2001), with damage in these areas potentially affecting larger-scale ecosystem processes such as drainage patterns, nutrient flows, water quality and aquatic species composition.

Whereas trampling effects are important issues for outdoor piggeries (Evans 1990), and to a lesser extent free-range poultry operations (Boardman and Evans 1994), feral pig populations, which constitute a small proportion of total pork production, are a major cause of land soil degradation across areas of Australia (Foster 2009) and are listed as a threatening process in the Environment Protection and Biodiversity Conservation Act 1999 (Cwlth). Trampling by feral goats, which are also listed 
under the Environment Protection and Biodiversity Conservation Act 1999 (Cwlth), has also been identified as having a major impact on vegetation. For example, the NSW Scientific Committee that determines which processes are threats to biodiversity, when making a final determination on feral goats as a threatening process, noted that the removal or destruction of vegetation together with trampling by ungulate herbivores such as goats decreases soil stability and contributes to erosion (NSW Scientific Committee 2009b).

\section{Invasive species}

The extensive grazing industries have been among the major contributors to the impact of invasive plant species on biodiversity (Grice 2006; Martin et al. 2006). Strong correlations can be made with the land-clearing discussion above where exotic pastures are introduced following clearing. In this context, the lamb/mutton industry should not be confused with the wider sheep industry, which has had a major impact on the spread of environmental weeds. Early attempts at aquaculture have contributed to invasive species of exotic fish in streams and have been attributed to the loss of some species of native inland-river fish in Australia (Arthington 1991).

The main invasive species associated with the cattle industry that create pressures on biodiversity are environmental and 'commercial' weeds (Grice 2006). Environmental weeds have been identified as among the most significant and costly environmental threats in Australia (Anon. 2007a). The impacts of weeds on biodiversity include competition with native species, loss of habitat for fauna and changes to fire and hydrological regimes.

In 1994, Lonsdale published a seminal paper that described the weed and agricultural potential of grasses that had been introduced for pastoralism (Lonsdale 1994). Weeds that have been introduced for pasture production can escape into natural systems, competing with native species and potentially altering fire regimes. Grice (2006) identified seven 'commercial weed' species associated with pasture development that have environmental impacts on a range of native ecosystems. This term refers to the proportion of plant species that are deliberately introduced and cultivated for commercial gain, despite their potential to invade natural systems. Examples include buffel grass in semiarid areas (Friedel et al. 2006; Smyth et al. 2009), species such as gamba grass in northern Australia (Douglas and Setterfield 2005) and para grass in the wetlands of north-eastern Australia (Williams and Collett 2009).

Martin et al. (2006) focussed their attention on the weeds of rangelands, identifying 160 species considered of threat to biodiversity in this region. Most of these plant species were found to have been deliberately introduced for forage or other commercial use (e.g. nursery trade). Among growth forms, shrubs and perennial grasses comprise over $50 \%$ of species that pose the greatest risk to rangeland biodiversity (Martin et al. 2006). The pressures that weeds put on biodiversity are many, with several endangered and vulnerable species already being seriously affected through competition. Gamba grass, for example, reduces tree cover, changes water availability, depletes nutrients and increases greenhouse gas emissions. Research shows that under climate change, gamba-fuelled fires will become more frequent, which will increase greenhouse gas emissions (Grice 2006).

\section{Pollution}

The forms of pollution associated with protein sources range from greenhouse gas emissions (see 'climate change' below) to nutrients, chemicals and sediments (Williams and Price 2009). Table 4 indicates that the highest potential relative contribution to pressures on biodiversity associated with pollution comes from intensive feedlot production systems (beef, pork, poultry, dairy and aquaculture). Sources of pollution associated with extensive industries include nutrient and sediment transport through erosion and other hydrological processes.

The potential impact of air, water and soil pollution is one of the few pressures that is found across all sources of protein studied in the present review. The sources of pollution are both pointsource and diverse, cover nutrients, sediments and emissions, and can have impacts on both aquatic and terrestrial biodiversity. The National Land and Water Resources Audit (NLWRA 2001a) assessment of selected agricultural practices provided a snapshot of water-borne sediments and nutrients at the turn of the millennium. Pastoral country used for cattle production in northern Australia was reported to be the most significant source of sheet erosion, with this region being the area where river suspended sediment loads had most increased. The National Land and Water Resources Audit (NLWRA 2001a) report found that $\sim 90 \%$ of suspended sediment loads reaching marine and nearshore environments was derived from $20 \%$ of agricultural catchments, particularly in coastal regions of Queensland and NSW.

A more recent assessment of the erosion and potential pollution caused by agricultural practices is provided in the 2006 State of the Environment report (Beeton et al. 2006). The authors stated that Australia's agricultural land uses and practices have caused an increase in erosion through vegetation clearing and total grazing pressure. The rate of erosion in pasture lands is reported to have doubled from the rate under natural conditions, and there has been a five-fold increase for improved pastures. The hard hooves of exotic animals have been identified elsewhere (Yates et al. 2000; Drewry 2006) as a major source of soil degradation. The degree of degradation will depend on the nature of the grazing regime, the climate and the vegetation and soils found in the area being grazed.

In periods of high rainfall, erosion from grazing lands, combined with overstocking on farms in the Fitzroy Basin, can lead to transport of eroded material into marine ecosystems such as the Great Barrier Reef (reefED 2009). Cattle grazing covers $82 \%$ of land use in this catchment (NLWRA 2001b), much of it on cleared land. Brodie and Waterhouse (2009) concluded that the influence of land use such as grazing on sediment loads reaching the Great Barrier Reef is now well known at a regional scale. More work is required, however, to identify sources at finer scales, due to variability associated with hill-slope, stream-bank and gully erosion within individual catchments.

Water pollution has many elements, as demonstrated by the numerous indicators identified for this topic in the waterquality guidelines of the Queensland Environmental Protection 
Authority (QEPA 2006). For example, under the heading 'wastewater release', which is only one of several issues addressed, the potential direct impacts are listed as altered water temperature, increased water nutrient concentrations, increased water faecal and chemical contamination, increased water sediment load, increased plant detritus and debris in waterways and reduced recreational values. Most of these impacts can have detrimental impacts on biodiversity. Wastewater release is associated with high-density production of protein sources, such as cattle, pork and chicken feedlots. These industries are highly regulated, so the release of wastewater is a rare event. The dairy industry also has the potential to release wastewater/effluent and for excess nutrients to leak from pastures into waterways. Ways to manage effluent are still being developed by the dairy industry.

Tables 6 and 7 provide data on the amount of waste per annum for feedlots in Queensland, where many feedlot operations are concentrated. Cattle and poultry systems have similar percentage contents of solids and total nitrogen in their by-products, with poultry having higher concentrations of phosphorus and cattle higher levels of potassium. In comparison, piggeries have a very low percentage of solids in their by-products, but the highest content of total nitrogen. These figures illustrate the different challenges faced by high-density feedlots with different animals to manage and the potential impact if effluent escapes into the environment.

The release of nutrients and heavy metals into the environment from wastewater is a key threatening process. Nitrate nitrogen, for example, is soluble in water and so can be easily carried into lakes, wetlands, streams and groundwater. When it is consumed by people or animals, it can be converted into nitrate and cause health problems and even death. Similarly, ammonia and phosphorus which together with nitrogen are the most significant environmental concerns of intensive feedlots (Burgos and Burgos 2006; Burkholder et al. 2007), can contribute to death of a range of life forms (Francis-Floyd and Watson 1996; Lehane 1999). Pollution of waterways by chemicals used in livestock industries (including through manure spread on pastures from high-density operations), in particular hormonal growth promotants, has been identified as an area of potential concern for aquatic biodiversity (Williams et al. 2007; Allison 2008).

\section{Disease and pathogens}

Consumers are significantly concerned about pathogens in the environment, particularly in respect to agricultural activity (Powers and Angel 2008) and human health. Much of the concern about disease and pathogens is exacerbated by high-

Table 7. Percentage content of nutrient concentrations in by-products Source: Environmental Protection Agency (Qld) 2001

\begin{tabular}{lcccc}
\hline Content (\%) & Cattle & Piggery & Poultry & Mushroom \\
\hline Solids & 73 & 2 & 70 & 50 \\
Total N & 2.2 & 3.4 & 2.7 & 1.8 \\
P & 0.8 & 4.7 & 2.5 & 0.8 \\
K & 2.3 & 0.8 & 1.4 & 1.6 \\
\hline
\end{tabular}

profile influenza outbreaks such as avian influenza (Lee Ligon 2005) and swine flu (Herring 2009).

From a biodiversity aspect, the study of disease and pathogens is under-explored. The spread of disease and pathogens through the environment, particularly via waterways, can pose a threat to biodiversity (ADAS UK 2008), as shown by studies on amphibians (Daszak et al. 2003) and fish (Langdon 1989). The results in Table 4 however may reflect lack of data about the relationship between disease and pathogens and biodiversity. Intensive systems have been attributed a higher level of contribution to risk because of the capacity for disease to move more quickly between animals (Kautsky et al. 2000).

\section{Climate change}

In August 2009, the Australian Government released the first comprehensive study of the vulnerability of biodiversity in Australia to climate change (Steffen et al. 2009). The assessment found that Australia's biodiversity is at risk from even moderate climate change and is already under stress, for example, from habitat degradation, altered fire regimes and invasive species (as noted earlier in this paper). Climate change is likely to exacerbate these existing pressures, such as through declining water availability (Steffen et al. 2009). Auld and Keith (2009) referred to climate change as the most pervasive, least understood and least predictable of threatening processes, with impacts on biodiversity that are likely to be many and varied. While climate change represents a significant threat to biodiversity, as noted in the report by Steffen et al. (2009) and other ecologists, the key message is that it needs to be examined in the context of other ongoing pressures on natural systems and interactive effects considered. For example, Mac Nally et al. (2009) proposed that declines in woodland birds in even the largest areas of native vegetation in Victoria are exacerbated by climate change. Climate and atmospheric changes are also likely to impact on factors such as the quantity and reliability of forage production and forage quality for livestock, pest, disease and weed challenges and land-degradation processes (Howden et al. 2008), which will have a flow-on effect on biodiversity.

The contribution of protein sources to climate change is through their impact on greenhouse gas emissions. The agricultural sector as a whole contributes $\sim 18 \%$ of the total greenhouse gas emissions in Australia (Garnaut 2008). Among the protein sources reviewed, the beef cattle and sheep industries contribute $70.1 \%$ of the greenhouse gas emissions from agriculture, followed by the dairy industry at $11.6 \%$ (Fig. 4). The contribution of protein sources to greenhouse gas emissions

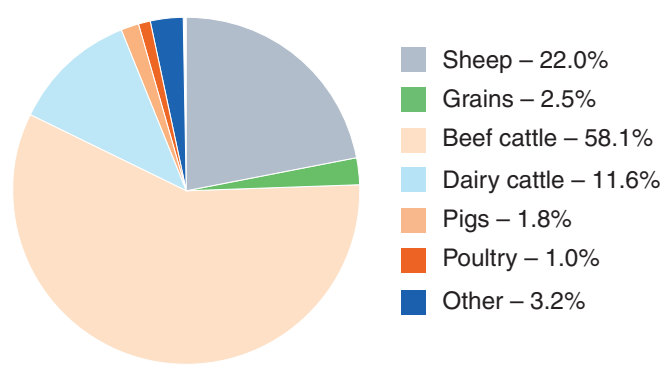

Fig. 4. Contribution of rural subsectors to Australia's agricultural emissions, excluding emissions from land clearing (source: Garnaut 2008). 
ranges from the release of carbon into the atmosphere through vegetation clearance, through to methane production by ruminants and management of greenhouse gases such as nitrogen from feedlots. Ruminant animals (cattle, sheep, goats) are the single largest source of Australia's agricultural greenhouse gas emissions (2861 $\mathrm{Gg} \mathrm{CO}_{2}$-e) and alone contribute $\sim 13 \%$ of Australia's total national emissions. In all, $97 \%$ of the greenhouse gas emissions are from enteric (digestive-tract) fermentation, with $3 \%$ from faeces. Animals such as pigs, chickens and kangaroos have much lower greenhouse gas emissions than ruminant animals (Garnaut 2008).

The companion study to the present review (Wiedemann et al. 2009) covers greenhouse gas emissions associated with a range of protein sources in considerable detail. If a full life-cycle analysis is undertaken, protein sources can also contribute to emissions through the use of various forms of transport, including trucks to get stock to feedlots, abattoirs and markets, as well as the transport that takes live animals and meat products to export markets. With red meat producers increasingly relying on exporting their product (Fletcher et al. 2009), the carbon footprint associated with overseas transport will also contribute to the total tally of greenhouse emissions.

\section{Other pressures, including direct decline of biota}

Two industries explored in this review deal with the direct harvest of wild biota (kangaroos and fish), which has been identified as a pressure on biodiversity. Of the two, fishing remains the major concern, with evidence of over-fishing in both Australian waters (Table 8) and elsewhere across the globe (Caton and McLoughlin 2005). Although consumer and interest groups hold strong and diverse views about kangaroo culling for meat or for reducing total grazing pressure, concerns about less common species being affected have been allayed by the scientific community (Olsen and Low 2006). Williams and Price (2009) also described the complex interactions between dingoes and biodiversity, which are increasingly thought to be positive. This has implications for the major culling programs of wild dogs, including dingoes, which are currently implemented to protect sheep and, increasingly, cattle.

Biotechnology presents several issues for biodiversity. Although sometimes touted as a technology with the potential to ease pressure on the environment, it can potentially also act to promote monocultures, reduce agricultural species diversity and cross-over and permanently affect the genes of native species (Johnson 2000).

\section{Industry and other responses}

In Australia, at least, the industries that have historically contributed most to the impact on biodiversity are those that are investing the most to various forms of responses. The high level of regulation imposed on Australian intensive feedlot industries in particular has reduced the impact of those industries on biodiversity. This is in contrast to intensive feedlots in America, where the nature of the production systems and regulatory environment has led to considerable attention, especially in the popular literature, about impacts on the environment, local communities and animal health (e.g. Imhoff 2010; Kirkby 2010). Steinfeld et al. (2010) concluded that it is inevitable that intensive livestock systems will meet the bulk of the growing global demand for animal products. In this context, they identify the need for urgent attention to be paid to the environmental, social and economic impacts of these industries by policy makers, producers and consumers.

Investment in natural resource management in Australia is another measure of the response by industry to environmental issues (Table 9). Although the biodiversity component is difficult to tease out from data provided in industry annual reports, it is clear that most industries are responding to social and governmental pressure to invest in environmental research and extension.

To reduce and manage the documented and potential impacts on biodiversity in Australia, the beef and sheep meat industries have implemented a broad range of responses, including research into sustainable land management practices and how the industry can minimise the impacts on biodiversity (Table 10). They have instigated several training and education initiatives, developed codes of practice, monitoring systems, management guidelines, which increasingly include environmental considerations, and resulted in changes to land and water management practices. In parallel with these initiatives, governments have introduced a range of legislation and regulations, supported research and training programs, and provided several incentives for improved management and restoration of landscapes.

Grazing management is an area where the red meat industry can, and has, improved production practices. Authors such as Bell and Allan (2000) and Quirk and McIvor (2003) have demonstrated how changing grazing management regimes can vary the efficiency with which meat is produced. Some of the onground practices in grazing enterprises that can contribute to improved biodiversity outcomes and that can be broadly applied are listed in Box 2. Importantly, as noted by Costa (2007) in a recent article on the environmental impact of the Australian livestock industry, grazing systems for cattle and sheep need to be integrated into landscape systems to sustain biodiversity. Taking a systems approach is important, both at the landscape and property scale.

Table 8. Trends in fish stocks managed by Australian Fisheries Management Authority (number of fisheries) Source: Caton and McLoughlin (2005)

\begin{tabular}{lrrrrrrrrrr}
\hline Stock status & 1992 & 1993 & 1994 & 1996 & 1997 & 1998 & 1999 & $2000-01$ & $2002-03$ & 2004 \\
\hline Not overfished & 17 & 29 & 28 & 28 & 20 & 18 & 17 & 19 & 20 \\
Overfished & 5 & 5 & 3 & 3 & 4 & 6 & 7 & 11 & 17 \\
Uncertain & 9 & 9 & 13 & 17 & 31 & 35 & 38 & 34 & 17 \\
Unclassified & 43 & 31 & 30 & 26 & 19 & 15 & 12 & 10 & 44 \\
\hline
\end{tabular}


Table 9. Natural-resource management (NRM) investment by Australia's rural Research and Development (R\&D) funding bodies (2005)

Source: Day (2005)

\begin{tabular}{lccr}
\hline Industry body & $\begin{array}{c}\text { NRM R\&D } \\
\left(10^{3}, \mathrm{~A} \$\right)\end{array}$ & $\begin{array}{c}\text { R\&D expenditure } \\
\left(10^{3}, \mathrm{~A} \$\right)\end{array}$ & \% NRM \\
\hline Australian Egg Corporation & & 1.55 & 0.0 \\
Australian Pork Limited & 0.70 & 6.45 & 10.9 \\
Sugar RandD Corporation & 1.00 & 7.02 & 14.2 \\
Forest and Wood Products RandD Corporation & 1.20 & 7.07 & 17.0 \\
Cotton RandD Corporation & 2.50 & 11.11 & 22.5 \\
Grape and Wine RandD Corporation & 2.00 & 15.08 & 13.3 \\
Land and Water Australia & 16.00 & 18.15 & 88.2 \\
Fisheries RandD Corporation & 15.90 & 25.57 & 62.2 \\
Dairy Australia Limited & 2.00 & 28.65 & 7.0 \\
Horticultural Australia Limited & 19.40 & 59.97 & 32.3 \\
Meat and Livestock Australia Limited & 6.06 & 62.60 & 9.7 \\
Aus Wool Innovation Limited & 8.40 & 65.72 & 12.8 \\
Grains RandD Corporation & 23.00 & 106.36 & 21.6 \\
\hline
\end{tabular}

Methods to reduce methane production from cattle and sheep are under investigation, although significant challenges remain. Challenges are also found in the calculation of the environmental costs and use of water in livestock production. Only by clearly demonstrating the impact of the beef and sheep industries on the environment generally, and biodiversity in particular - and by showing that it is being minimised and, where possible, reversedwill the overall negative perceptions of these industries begin to change. Developing and building on partnerships with groups such as Bush Heritage Australia and Greening Australia (Costa 2007) should lead to positive outcomes for both 'industries'.

The goat industry in Australia is largely based on wild, rangeland goats, which have been identified as a key threatening process to biodiversity in Commonwealth legislation. The two main responses associated with feral-goat management are the Threat Abatement Plan for Competition and Land Degradation by Unmanaged Goats (DEWHA 2008) and the commercial harvesting of rangeland goats. Although the commercial harvest of goats has been developed partially in response to the need to reduce their impact, there has been minimal research on the impact of this practice on biodiversity. The commercial harvest of kangaroos and wallabies is also based on wild populations of six common species and is regulated through a quota system (Williams and Price 2009). These species are native to Australia and are thus adapted to local conditions. Changes to the environment due to agriculture however have seen their numbers increase to unsustainable levels in some regions. This has led to subsequent impacts on systems managed for both production and conservation. Australia's Rural Industries R\&D Corporation has initiated a native animal research program to develop native industries in sustainable ways (RIRDC 2009).

Chicken meat, egg and pork industries each have their own national or state-based environmental guidelines or codes of practice; however, biodiversity is not dealt with explicitly in any of these. Although these guidelines and codes of practice deal with effluent management, and therefore the reduced threat to biodiversity (principally aquatic), considerable attention is paid to odour management and animal health and safety. These issues are frequently cited as being of significant concern to the general public (Verbeke et al. 1999). Government legislation significantly influences the activities of these industries.

Regulation is also the primary means of limiting the impact of fishing (non-aquaculture) on biodiversity in Australia (AFMA 2009). The Fisheries Management Act 1991 (Cwlth), interpreted by AFMA, requires that stocks be maintained at a sustainable level and, where necessary, rebuilt to ensure maximum intergenerational equity. It also requires managing fisheries so as to minimise the impact of fishing on biological diversity and ecosystem habitat. As part of this process, research into environmentally friendly fishing methods and by-catch minimisation is seen as a priority.

Australia has largely adopted a property rights approach to fishing management to meet the obligations of the Fisheries Management Act 1991, although the use of marine protected areas (MPAs) is also employed. These two management approaches are based on distinctly different principles that have given rise to confusion and conflict (Baelde 2005). The 'rights'-based system is based on licensing and quotas, with each fishery having its own separate rights based on quota assessments (AFMA 2009). Fishers have their boats licensed and are allocated a catch quota, and may use their right or sell or lease it to other fishers. The AFMA is responsible for managing this system. MPAs largely exclude fishing from zones designated under the Environment Protection and Biodiversity Conservation Act 1999 (Cwlth).

The issue of by-catch has been addressed by AFMA through the development of by-catch actions plans (BAPs) developed for each specific fishery (AFMA 2009). Voluntary-based environmental management systems (EMS) are also used by some parts of the fishing sector, responding to consumer perceptions about the efficacy of the fishing industry (http:// www.msc.org/about-us, verified 28 June 2009).

The decline in wild fisheries around the world and the subsequent impacts on biodiversity has led to an increasing focus on aquaculture, with Australia producing increasing amounts of salmon and other sought-after products. Aquaculture activities are generally subject to strict regulatory control. 
Table 10. Industry and other responses to the state of biodiversity as a result of multiple pressures associated with the cattle industry $\mathrm{R}, \mathrm{D} \& \mathrm{E}$, research, development and extension

Sector/group responding
Meat \& Livestock Australia
Industry groups
R\&D Corporations (other than
MLA), e.g. RIRDC, LWA

Private land managers (1)

Private land managers (2)

Rangelands Australia (Partners include DAFF, Queensland Govt, MLA and the Uni of Queensland)

Government - Commonwealth and State

Broad responses
R,D\&E programs and projects

Training and education programs

Codes of practice and management guidelines

Fund and/or manage R\&D programs; develop and distribute communication products, including management guidelines

Pasture and biodiversity monitoring, certification/EMS; property management planning; involvement in research

Changed management practices

Developed Australia's only postgraduate coursework programs specifically in rangeland management

Legislation, regulations, policies and programs
Research organisations and programs (e.g. CSIRO, universities, State Primary Industry and Environment Departments); NRM programs (NHT and $\mathrm{C} 4 \mathrm{oC}$ ); CSIRO

\section{Best management practices}

Incentive programs

On-ground management, training and incentive programs
Example/s of relevant programs and relevant references

Evergraze; Grain and Graze (Bridle et al. 2009); Pigeon Hole project (Fisher et al. 2006); strategic RandD plans for Northern Beef, Southern Beef and Feedlots

EDGENetwork - Grazing Land Management Program (northern Australia), Managing Living Systems; Prograze (southern Australia). 'Tips and Tools'

National Beef Cattle Feedlot Environmental Code of Practice; National Guidelines for Beef Cattle Feedlots; National Feedlot Accreditation Scheme

Methane to Markets in Australian Agriculture Program (RIRDC manages as part of an international program); Riparian Lands R\&D Program and the Native Vegetation R\&D Program (both managed by LWA and set up to address the management of sustainable agricultural landscapes, including biodiversity)

The Pigeon Hole research project was conducted on a Heytesbury property; NAPCO have ISO14001 certification for the feedlot near Toowoomba and numerous other measures in place in their extensive grazing systems (Bentley et al. 2008); an EMS has been developed by a group of cattle farmers (Gippsland Naturally Pty Ltd) and is used as part of their marketing program for their 'Enviromeat' product

Changed management practices include: rotational/tactical grazing, holistic management (all approaches involve spelling pastures), stock exclusion, weed eradication, planting crop/pasture legumes, use of perennial pastures, monitoring of watertables, fire management, closing artificial watering points; stopping or reducing vegetation clearance; nature reserves and other areas set aside for conservation

Offer a Graduate Certificate, Graduate Diploma and Master in Rangeland Management

- Queensland Vegetation Management Act (1999) (Williams and Price 2008)

- Delbessie Agreement (2006) for rural leasehold land in Queensland (Department of Environment and Resource Management 2009)

- Regulations and codes of practice for high-density feedlots (state level)

- Great Artesian Basin Sustainability Initiative - a joint Commonwealth/Queensland government program

- Policy on the containment of Leuceana (Queensland)

- National Residue Survey

- Australian Rangelands Information System (ACRIS)

Biograze, Watersmart, Tropical Savannas CRC (a major R,D\&E program in northern Australia with a focus on pastoralism), projects funded through $\mathrm{NHT}$ and $\mathrm{C} 4 \mathrm{oC}$ (e.g. the NTCA received funding in 2009); Sustainable Ecosystems (CSIRO) undertakes several research projects in cattle production systems; the CSIRO Water for a Healthy Country Flagship has a Sustainable Grazing Program Great Barrier Reef Catchments Node

Cattle grazing in the north and south of Western Australia (e.g. DPI 2005)

Managed by regional NRM organisations or non-profit organisations

Fitzroy Basin Association (as an example) - funds and manages programs such as the Biodiversity Incentive Scheme; Sustainable Landscape Program; Assessing Ground Cover and Property Planning. Burdekin region guidelines for waterway health (Coughlin et al. 2008) 
Table 10. (continued)

\begin{tabular}{lcc}
\hline Sector/group responding & Broad responses & Example/s of relevant programs and relevant references \\
\hline $\begin{array}{l}\text { Non-profit conservation groups, } \\
\text { e.g. Bush Heritage Australia and } \\
\begin{array}{c}\text { Australian Wildlife Conservancy } \\
\text { Other sectors/examples }\end{array}\end{array}$ & $\begin{array}{c}\text { Purchase properties in northern } \\
\text { Australia for conservation outcomes }\end{array}$ & $\begin{array}{c}\text { Remove cattle from properties in addition to managing other pressures } \\
\text { on biodiversity }\end{array}$ \\
& $\begin{array}{c}\text { Publications and other communication } \\
\text { material; codes of practice }\end{array}$ & $\begin{array}{c}\text { Example publications on the potential to integrate conservation and } \\
\text { production, including the use of case studies, as part of a profitable } \\
\text { farming systems include Mokany et al. 2006, Staton and O'Sullivan } \\
\text { 2006, Dorrough et al. 2008, Waters and Hacker 2008; code of } \\
\text { practice for the commercially grown Leuceana }\end{array}$ \\
\hline
\end{tabular}

Box 2. Grazing management actions for biodiversity stewardship

- Matching grazing systems to carrying capacity at several scales.

- Taking total grazing pressure into consideration when calculating sustainable stocking rates, both in exotic and native pasture systems.

- Elevating the concept of total grazing pressure and grazing regimes into the language of grazing should help bring a better understanding of impacts of grazing on biodiversity.

- Setting aside some areas from grazing by stock and feral animals will help protect and maintain species that are sensitive to grazing.

- Temporary destocking, especially before the major impacts of drought - which is best done in a risk-management framework.

- Taking into account the variability in impacts and responses, both in space and time, is important when trying to understand and describe the impact of grazing systems.

- A diversity of management practices and vegetation types is the key to maintaining biodiversity, from the local to the landscape scale.

- Importantly, robust and long-term monitoring systems are required to measure the impact of management on biodiversity and production systems.

The grains industry has invested heavily for many years in improved cultivation practices that minimise soil disturbance and maximise retention of water, and make best use of this resource when needed (Beeston et al. 2005). The primary purpose of this effort has not been for biodiversity outcomes, although there are benefits to soil biota (Hobbs 2007). The use of buffer and vegetative zones for spray drift (Ucar and Hall 2001) and the incorporation of woody plants in alleys to manage deep drainage and provide shelter for birds and invertebrates (Harper et al. 2000; Coles et al. 2004) have been advocated across cropping regions of Australia. More recently, the grains industry has begun to explore the potential of integrated pest management (Horne and Page 2008), long popular in the cotton industry (Fitt 2000) and to some extent among the horticultural industries (McDougall et al. 1999), as a means of reducing reliance on chemicals.

Dairying for Tomorrow, which is managed by Dairy Australia, is the main environmental program of the dairy industry (Anon. $2007 b$ ). The program is national in scope and focuses on natural resource management (NRM), with a goal to bring together industry and community partners to develop and implement sound environmental management practices. Some of the environmental measures dairy farmers are putting in place as part of this program are reducing fertiliser loss, changing effluent systems, retaining native bush and fencing off waterways. Publications either funded or co-funded by Dairy Australia include information about shelterbelts and their biodiversity management, as well as riparian and fertiliser management (Gourley et al. 2007). Dairy Australia also funds research on topics such as water quality (e.g. Holz 2007) to help inform effluent management. Like the other intensive industries covered in the present review, the dairy industry is subject to an array of regulations.

\section{Conclusions}

This review has focussed largely on Australia's red meat industries, focusing on cattle and sheep, with attention paid to their comparative performance to other protein sources. The conceptual challenges in comparing the performance of different industries in respect to biodiversity (water and greenhouse gases are more readily quantifiable) have been acknowledged. Despite these challenges, the results overall demonstrate that the beef industry has the largest relative potential contribution to the impact on terrestrial biodiversity in Australia, by both the area covered and the nature of the impacts. This includes the area of native vegetation cleared for grazing, the impacts of over-grazing and trampling, the amount of grain used in high-density feedlots and the quantity of greenhouse gases emitted.

Even if current management practices incorporate biodiversity conservation into their objectives, the legacy of past land-use practices casts a long shadow over the beef and sheep industries in Australia. This has led to widespread and persistently held perceptions that these industries have had a major and negative impact on the nation's biodiversity, with ongoing calls to reduce the number of stock and replace them with an industry based on kangaroos (e.g. Wilson and Edwards 2008). On a global scale, the impact of meat production on natural systems through clearing (for both pastures and grain to feed cattle in feedlots), overgrazing, pollution of waterways and greenhouse gas emissions has seen similar calls to reduce consumption and hence the number of stock.

Many industry initiatives in Australia, including those of the beef and sheep industries, have the potential to improve the management of biodiversity. As always, the crunch comes in terms of their implementation. To minimise the impact of beef 
and sheep meat systems on biodiversity, the conservation of natural resources has to become a core and integral part of production systems, rather than it being perceived as an optional extra if times are good. The practices of innovative land managers implementing sustainable land and water management can be used as examples to others and applied more widely. Managing for biodiversity outcomes needs to be rewarded in the market and through government programs, compared with some of the perverse policies in the past. In this context, the concept of stewardship payments for the ecosystem services (such as carbon, water and biodiversity) provided by the farming community to the wider society warrants further consideration (e.g. Comerford et al. 2006; Stoneham 2007; Whitten et al. 2009).

\section{Acknowledgements}

This paper summarises the findings of a report funded by Meat \& Livestock Australia (MLA). Both MLA and the referees for this paper provided comments that gave the authors much food for thought.

\section{References}

Abbott I, Burrows N (Eds) (2003) 'Fire in ecosystems of south-west Western Australia: impacts and management.' (Backhuys Publishers: Leiden, The Netherlands)

ADAS UK (2008) The environmental impact of livestock production. Report for the Department for Environment, Food and Rural Affairs. DEFRA, London.

Allison G (2008) 'Steroid transport from agroecosystems: a review.' (DPI: Queenscliff, Vic.)

Anon. (1996) 'Fire and biodiversity. The effects and effectiveness of fire management.' Biodiversity series, paper no. 8, Biodiversity Unit. (Department of the Environment, Sport and Territories: Canberra)

Anon. (2007a) 'Australian Weeds Strategy - A national strategy for weed management in Australia.' Natural Resource Management Ministerial Council (2006). (Australian Government Department of the Environment and Water Resources: Canberra)

Anon. (2007b) 'Dairy Australia Natural Resource Management Strategy 2007-2010.' (Dairy Australia). Available at http://www.dairying fortomorrow.com/uploads/documents/file/DA\%20NRM\%20Strategy $\%$ 202007.pdf [Verified June 2009]

Arthington AH (1991) The ecological and genetic impacts of introduced and translocated freshwater fishes in Australia. Canadian Journal of Fisheries and Aquatic Sciences 48, 33-44.

Arthington A, Bunn SE, LeRoy Poff N, Naiman RJ (2006) The challenge of providing environmental flow rules to sustain river ecosystems. Ecological Applications 16, 1311-1318. doi:10.1890/1051-0761(2006) 016[1311:TCOPEF]2.0.CO;2

Asner GP, Elmore AJ, Olander LP, Martin RE, Harris AT (2004) Grazing systems, ecosystem responses, and global change. Annual Review of Environment and Resources 29, 261-299. doi:10.1146/annurev. energy.29.062403.102142

Auld TD, Keith DA (2009) Dealing with threats: integrating science and management. Ecological Management \& Restoration 10(S1), S79-S87. doi:10.1111/j.1442-8903.2009.00447.x

Auster PJ, Langton RW (1999) The effects of fishing on fish habitat. American Fisheries Society Symposium 22, 150-187.

Australian Bureau of Agriculture and Resource Economics (2007a) 'Australian food statistics 2007.' (ABARE: Canberra)

Australian Bureau of Agriculture and Resource Economics (2007b) 'Australian commodity statistics 2007.' (ABARE: Canberra)
Australian Bureau of Agriculture and Resource Economics (2008) 'Australian fishing statistics 2007.' Available at http://www.abareconomics.com/ interactive/08afs_june/ [Verified 5 May 2009]

Australian Bureau of Statistics (2006) Australian water account 2004-05. Report 4610.0. ABS, Canberra.

Australian Bureau of Statistics (2009) Agricultural commodities Australia. 2007-2008. Report 7121.0. ABS, Canberra.

Baelde P (2005) Interactions between the implementation of marine protected areas and right-based fisheries management in Australia. Fisheries Management and Ecology 12, 9-18. doi:10.1111/j.13652400.2004.00413.x

Baumont R, Prache S, Meuret M, Morand-Fehr P (2000) How forage characteristics influence behaviour and intake in small ruminants: a review. Livestock Production Science 64, 15-28. doi:10.1016/S03016226(00)00172-X

Beardmore JA, Mair GC, Lewis RI (1997) Biodiversity in aquatic systems in relation to aquaculture. Aquaculture and Research 28, 829-839. doi:10.1111/j.1365-2109.1997.tb01007.x

Beeston G, Stephens D, Nunweek M, Walcott J, Ranatunga K (2005) GRDC strategic planning for investment based on agro-ecological zones. Final report to GRDC, June 2005. Bureau of Rural Sciences, Canberra.

Beeton RJS, Buckley KI, Jones J, Morgan D, Reichelt RE, Trewin D (2006) Australia State of the Environment 2006. Independent report to the Australian Government Minister for the Environment and Heritage. DEWHA, Canberra.

Bell AK, Allan CJ (2000) PROGRAZE - an extension package in grazing and pasture management. Australian Journal of Experimental Agriculture 40, 325-330. doi:10.1071/EA98017

Bentley D, Hegarty RS, Alford AR (2008) Managing livestock enterprises in Australia's extensive rangelands for greenhouse gas and environmental outcomes: a pastoral company perspective. Australian Journal of Experimental Agriculture 48, 60-64. doi:10.1071/EA07210

Beveridge MCM, Ross LG, Kelly LA (1994) Aquaculture and biodiversity. Ambio 23, 497-502.

Boardman J, Evans JR (1994) Soil erosion in Britain: a review. In 'Conserving soil resources: European perspectives'. (Ed. RJ Rickson) pp. 3-12. (CAB International: Wallingford, UK)

Bradstock RA, Williams JE, Gill AM (Eds) (2002) 'Flammable Australia: fire regimes and the biodiversity of a continent.' (Cambridge University Press: Cambridge, UK)

Brand TS (2000) Grazing behaviour and diet selection by Dorper sheep. Small Ruminant Research 36, 147-158. doi:10.1016/S0921-4488(99)00158-3

Bridle K, Fitzgerald M, Green D, Smith J, McQuillan P, Lefroy T (2009) Relationships between site characteristics, farming system and biodiversity on Australian mixed farms. Animal Production Science 49, 869-882. doi:10.1071/AN09042

Brodie J, Waterhouse J (2009) Assessment of relative risk of the impacts of broadscale agriculture on the Great Barrier Reef and priorities for investment under the Reef Protection Package. Stage 1 report. ACTFR report number 09/17. Australian Centre for Tropical Freshwater Research, Townsville, Qld.

Burgman MA, Keith D, Hopper SD, Widyatomoko D, Drill C (2007) Threat syndromes and conservation of the Australian flora. Biological Conservation 134, 73-82. doi:10.1016/j.biocon.2006.08.005

Burgos A, Burgos SA (2006) Environmental approaches to poultry feed formulation and management. International Journal of Poultry Science 5, 900-904. doi:10.3923/ijps.2006.900.904

Burkholder JM, Libra R, Weyer P, Heathcote S, Kolpin D, Thorne PS, Wichman M (2007) Impacts of waste from concentrated animal feeding operations on water quality. Environmental Health Perspectives 115, 308-312. doi:10.1289/ehp.8839

Butler DW, Fairfax RJ (2003) Buffel grass and fire in a Gidgee and Brigalow woodland: a case study from central Queensland. Ecological Management \& Restoration 4, 120-125. doi:10.1046/j.1442-8903.2003.00146.x 
Canonico GC, Arthington A, McCrary JK, Thieme ML (2005) The effects of introduced tilapias on native biodiversity. Aquatic Conservation: Marine \& Freshwater Ecosystems 15, 463-483. doi:10.1002/aqc.699

Caton A, McLoughlin K (2005) Status of fish stocks managed by the Australian Government. Available at http://affashop.gov.au/product. asp?prodid=12985 [Verified 5 May 2009]

Cogger H, For H, Johnson C, Holman J, Butler D (2003) 'Impacts of land clearing on Australian wildlife in Queensland.' (World Wildlife Foundation Australia: Sydney)

Coles NA, Farmer D, Cattlin T, Stanton D (2004) Managing water, the key to preserving biodiversity in the dryland agricultural areas of Western Australia. In 'Proceedings of international conference on hydrology science and practice for the 21st century', July 2004. Vol. 2, pp. 56-63. (BHS: London)

Comerford E, Clouston B, Greiner R (2006) Designing stewardship payments for ecosystem services. Department of Natural Resources, Mines and Water, Brisbane.

Costa N (2007) Reducing the meat and livestock industry's environmental impact. Nutrition \& Dietetics 64(Suppl. 4), S185-S191. doi:10.1111/ j.1747-0080.2007.00210.x

Coughlin T, O'Reagain P, Nelson B, Butler B, Burrows D (2008) 'Managing for water quality within grazing lands of the Burdekin Catchment Guidelines for Land Managers.' (Burdekin Solutions Ltd: Townsville, Qld)

Coutts-Smith AJ, Mahon PS, Letnic M, Downey PO (2007) 'The threat posed by pest animals to biodiversity in New South Wales.' (Invasive Animals Cooperative Research Centre: Canberra)

Dairy Australia (2009) Information note - options for non-replacement calves. Dairy Australia and Australian Dairy Farmers. Available at http://www.dairyaustralia.com.au/Farm/Animal-Health/ /media/ Documents/Farm/Animal\%20Health/Options\%20for\%20nonreplacement $\% 20$ calves/Options $\% 20$ for $\% 20$ calves $\% 20$ Information $\%$ 20note.ashx [Verified May 2009]

Daszak P, Cunningham AA, Yatt AD (2003) Infectious disease and amphibian population declines. Diversity \& Distributions 9, 141-150. doi:10.1046/ j.1472-4642.2003.00016.x

Day PR (2005) 'RDC profiles 2004-05: A summary of rural research \& development corporations and companies.' (Land \& Water Australia: Canberra)

Deo RC, Syktus JI, McAlpine CA, Lawrence PJ (2009) Impact of historical land cover change on daily indices of climate extremes including droughts in eastern Australia. Geophysical Research Letters 36, L08705. doi:10.1029/2009GL037666

Department of Environment and Resource Management (2009) 'Delbessie agreement (State Rural Leasehold Land Strategy). Guidelines for determining lease land condition. Version 1.1.' (Department of Environment and Resource Management: Brisbane)

Department of Primary Industries (2005) The grazing of cattle in the northern pastoral areas of Western Australia. Best management practice 2005. Department of Planning and Infrastructure, WA, Perth.

Department of Primary Industries and Water (2009) Annual waterways report. Montagu Catchment. Water Assessment Branch, DPIW, Hobart.

DEWHA (2008) 'Threat abatement plan for competition and degradation by unmanaged goats.' (Department of Environment, Water, Heritage and the Arts: Canberra)

Dickman C (2007) 'A fragile balance: the extraordinary story of Australian marsupials.' (Craftsman House: Sydney)

Dorrough J, Moll J, Crosthwaite J (2007) Can intensification of temperate Australian livestock production systems save land for native biodiversity? Agriculture Ecosystems \& Environment 121, 222-232. doi:10.1016/ j.agee.2006.12.012

Dorrough J, Stol J, McIntyre S (2008) 'Biodiversity in the paddock. A land manager's guide.' (Future Farm Industries CRC: Perth)
Douglas MM, Setterfield SS (2005) Impacts of exotic tropical grasses: lessons from gamba grass in the Northern Territory. In 'Proceedings of the eighth Queensland weed symposium, Townsville'. pp. 69-73.

Drewry JJ (2006) Natural recovery of soil physical properties from treading damage of pastoral soils in New Zealand and Australia: a review. Agriculture Ecosystems \& Environment 114, 159-169. doi:10.1016/ j.agee.2005.11.028

Duncan D, Moxham C, Read C (2007) 'Effect of stock removal on woodlands in the Murray Mallee and Wimmera Bioregions of Victoria.' (DSE: Melbourne)

Dyer R, Jacklyn P, Partridge I, Russell-Smith J, Williams D (2001) 'Savanna burning. Understanding and using fire in northern Australia.' (Tropical Savannas CRC: Brisbane)

Eldridge DJ (1996) Distribution and floristics of terricolous lichens in soil crusts in arid and semi-arid New South Wales, Australia. Australian Journal of Botany 44, 581-599. doi:10.1071/BT9960581

Environmental Protection Agency (Qld) (2001) Environmental Management Program for beneficial use of biosolids information sheet, 27 July 2001. Environmental Protection Agency, Brisbane.

Evans R (1990) Soils at risk of accelerated erosion in England and Wales. Soil Use and Management 6, 125-131. doi:10.1111/j.1475-2743.1990. tb00821.x

Fairfax RJ, Fensham RJ (2000) The effect of exotic pasture development on floristic diversity in central Queensland, Australia. Biological Conservation 94, 11-21. doi:10.1016/S0006-3207(99)00169-X

Fensham RJ, Fairfax RJ (2008) Water-remoteness for grazing relief in Australian arid-lands. Biological Conservation 141, 1447-1460. doi:10.1016/j.biocon.2008.03.016

Fischer J, Stott J, Zerger A, Warren G, Sherren K, Forrester RI (2009) Reversing a tree regeneration crisis in an endangered ecoregion. Proceedings of the National Academy of Sciences, USA 106, 10386-10391. doi:10.1073/pnas.0900110106

Fisher A, Hunt L, James C, Landsberg J, Phelps D, Smyth A, Watson I (2004) Review of total grazing pressure management issues and priorities for biodiversity conservation in rangelands: a resource to aid NRM planning. Desert Knowledge CRC project report no. 3 (August 2004). Desert Knowledge CRC and Tropical Savannas Management CRC, Alice Springs, NT.

Fisher A, Low-Choy SJ, Milne DJ, Ash AJ, Cowley RA, Hunt LP, MacDonald N, Petty S (2006) Maintaining biodiversity values under pastoral intensification in the Australian Tropical savannas. In 'Cutting edge, Renmark 2006: Australian Rangeland Society 14th biennial conference, Renmark, SA, 3-7 September 2006'. (Ed. P Erkelenz) pp. 142-145. (Australian Rangeland Society: Unley, SA)

Fitt GP (2000) An Australian approach to IPM in cotton: integrating new technologies to minimise insecticide dependence. Crop Production 19, 793-800. doi:10.1016/S0261-2194(00)00106-X

Fletcher S, Buetre B, Morey K (2009) The value of the red meat industry to Australia. ABARE Research report 09.13, June, for the Australian Government Department of Agriculture, Fisheries and Forestry, Canberra.

Food and Agriculture Organisation (2008) 'State of the world's fisheries and aquaculture.' (FAO: Rome)

Ford H, Barrett GW, Saunders DA, Recher HF (2001) Why have birds in the woodlands of Southern Australia declined? Biological Conservation 97, 71-88. doi:10.1016/S0006-3207(00)00101-4

Foster M (2009) 'Emerging animal and plant industries - their value to Australia.' 2nd edn. (RIRDC: Canberra)

Francis-Floyd R, Watson C (1996) Ammonia. Report FA-16 Florida Cooperative Extension Service. (University of Florida: Gainesville, FL)

Franklin DC, Whitehead PJ, Matthews J, McMahon P, McIntyre D (2005) Geographic patterns and correlates of the decline of granivorous birds in northern Australia. Wildlife Research 32, 399-408. doi:10.1071/ WR05052 
Friedel M, Puckey H, O’Malley C, Waycott M, Smyth A, Miller G (2006) Buffel grass: both friend and foe. An evaluation of the advantages and disadvantages of buffel grass use and recommendations for future research, report no. 16. (Desert Knowledge Cooperative Research Centre: Alice Springs, NT)

Garnaut R (2008) 'The Garnaut climate change review: final report.' (Cambridge University Press: London)

George RJ, McFarlane DJ, Speed RJ (1996) The consequences of a changing hydrologic environment for native vegetation in south western Australia. In 'Nature conservation 4: the role of networks'. (Eds DA Saunders, JL Craig, EM Mattiske) pp. 9-22. (Surrey Beatty: Sydney)

Gibbons P, Zerger A, Jones S, Ryan P (2006) Mapping vegetation condition. Ecological Management \& Restoration 7(Suppl. 1), S1-S2.

Gill AM (1975) Fire and the Australian flora: a review. Australian Forestry 38, 4-25.

Gill AM, Woinarski JCZ, York A (1999) 'Australia's biodiversity-responses to fire. Plants, birds and invertebrates.' Biodiversity technical paper no. 1 . (Environment Australia: Canberra)

Glanznig A (1995) 'Native vegetation clearance, habitat loss and biodiversity decline.' Biodiversity series, paper no. 6. (Department of the Environment, Sport and Territories: Canberra)

Gourley CJP, Melland AR, Waller AR, Awty IM, Smith AP, Oeverell KI, Hannah MC (2007) 'Making better fertiliser decisions for grazed pastures in Australia.' (Department of Primary Industries: Melbourne) Available at http://www.asris.csiro.au/downloads/BFD/Making\% 20Better\%20Fertiliser\%20Decisions $\% 20$ for $\% 20$ Grazed $\% 20$ Pastures $\%$ 20in\%20Australia.pdf [Verified 26 July 2010]

Graetz RD (1998) The terrestrial carbon pools of the Australian continent: an assessment of their size, dynamics and tractability. Reporting a project undertaken for the National Greenhouse Gas Inventory. Environment Australia. Department of the Environment, Sport and Territories. CSIRO Earth Observation Centre, Canberra.

Grice AC (2006) Commercially valuable weeds: can we eat our cake without choking on it? Ecological Management \& Restoration 7, 40-44. doi:10.1111/j.1442-8903.2006.00246.x

Habermehl MA (2006) The Great Artesian Basin, Australia. In 'Nonrenewable ground water resources. A guidebook on sociallysustainable management for water-policy makers'. IHP-VI, series on groundwater no. 10. (Eds S Foster, DP Loucks) pp. 82-88. (United Nations Educational, Scientific and Cultural Organization (UNESCO): Paris)

Hacker R, McLeod S (2003) 'Living with kangaroos. A guide to kangaroos and their management in the Murray-Darling Basin.' (NSW Agriculture: Orange, NSW)

Harper R, Hatton T, Crombie D, Dawes W, Abbott L, Challen R, House C (2000) 'Phase farming with trees.' (RIRDC: Canberra)

Helm A, Hanski I, Partel M (2006) Slow response of plant species richness to habitat loss and fragmentation. Ecology Letters 9, 72-77.

Henzell T (2007) 'Australian agriculture: its history and challenges.' (CSIRO: Melbourne)

Herring A (2009) Viral panic, vulnerability and the next pandemic. In 'Risk and adversity.' (Eds C Panter-Brick, A Fuentes) pp. 78-97. (Berghahn Books: New York)

Ho C, Armstrong D, Malcolm B (2004) Impacts of changing water price and availability on irrigated dairy farms in northern Victoria. In 'AARES conference proceedings'. Available at http://www.aares.info/files/ 2004_ho.pdf [Verified May 2009]

Hobbs PR (2007) Conservation agriculture: what is it and why is it important for the sustainable food production? Journal of Agricultural Science 145, 127-137. doi:10.1017/S0021859607006892

Holmes J (2000) Pastoral lease tenures as policy instruments. In 'Environmental history and policy: still settling Australia'. (Ed. S Dovers) pp. 212-242. (Oxford University Press: Oxford, UK)
Holmes JH, Knight LR (1994) Pastoral lease tenure in Australia: historical relic or useful contemporary tool. The Rangeland Journal 16, 106-121. doi:10.1071/RJ9940106

Holz GK (2007) Montagu River catchment: intensive grazing, drainage and water quality. NW Tasmania. Final report. TIAR, University of Tasmania, Hobart.

Holz GK (2009) Seasonal variation in groundwater levels and quality under intensively drained and grazed pastures in the Montagu catchment, NW Tasmania. Agricultural Water Management 96, 255-266. doi:10.1016/ j.agwat.2008.08.006

Horne PA, Page J (2008) 'Integrated pest management for crops and pastures.' (CSIRO Publishing: Melbourne)

Howden M, Crimp SJ, Stokes CJ (2008) Climate change and Australian livestock systems: impacts, research and policy issues. Australian Journal of Experimental Agriculture 48, 780-788. doi:10.1071/EA08033

Howes AL, McAlpine CA (2008) 'The impact of artificial watering points on rangeland biodiversity: a review.' WaterSmart Pastoral Production Project literature review. Working paper 15. (Desert Knowledge CRC: Alice Springs, NT)

Hunt LP, Petty S, Cowley R, Fisher A, Ashe AJ, MacDonald N (2007) Factors affecting the management of cattle grazing distribution in northern Australia: preliminary observations on the effect of paddock size and water points. The Rangeland Journal 29, 169-179. doi:10.1071/RJ07029

Imhoff D (2010) 'The CAFO reader. The tragedy of intensive animal factories.' (University of California Press: Berkeley, CA)

James CD, Landsberg J, Morton SR (1999) Provision of watering points in the Australian arid zone: a review of effects on biota. Journal of Arid Environments 41, 87-121. doi:10.1006/jare.1998.0467

Jansen A, Healey M (2003) Frog communities and wetland condition: relationships with grazing by domestic livestock along an Australian floodplain river. Biological Conservation 109, 207-219. doi:10.1016/ S0006-3207(02)00148-9

Jansen A, Robertson AI (2001) Relationships between livestock management and the ecological condition of riparian habitats along an Australian floodplain river. Journal of Applied Ecology 38, 63-75. doi:10.1046/ j.1365-2664.2001.00557.x

Jansen A, Askey-Doran M, Pettit N, Price P (2007a) Impacts of land management practices on riparian land. Chapter 9. In 'Principles for riparian lands management'. (Eds S Lovett, P Price) pp. 159-174. (River Landscapes, Land \& Water Australia: Canberra)

Jansen A, Robertson A, Thompson L, Wilson A, Watts R (2007b) 'Rapid appraisal of riparian condition: Technical guideline for the wool-growing districts of Tasmania.' (Land \& Water Australia: Canberra)

Johnson B (2000) Genetically modified crops and other organisms: implications for agricultural sustainability and biodiversity. In 'Agricultural biotechnology and the poor'. Proceedings of an international conference, Washington, DC, 21-22 October 1999. (Eds GJ Persley, MM Lantin) pp. 131-138. (Consultative Group on International Agricultural Research)

Kautsky N, Ronnback P, Tedengren M, Troell M (2000) Ecosystem perspectives on management of disease in shrimp pond farming. Aquaculture 191, 145-161. doi:10.1016/S0044-8486(00)00424-5

Kingsford R (2000) Ecological impacts of dams, water diversions and river management on floodplain wetlands in Australia. Austral Ecology 25, $109-127$.

Kirkby D (2010) 'Animal factory. The looming threat of industrial pig, dairy, and poultry farms to humans and the environment.' (St Martin's Press: New York)

Kirkpatrick J, Bridle K (Eds) (2007) 'People, sheep and nature conservation. The Tasmanian experience.' (CSIRO: Melbourne)

Kutt AS, Woinarski JCZ (2007) The effects of grazing and fire on vegetation and the vertebrate assemblage in a tropical savanna woodland in northeastern Australia. Journal of Tropical Ecology 23, 95-106. doi:10.1017/ S0266467406003579 
Landsberg JJ, James CD, Morton SR, Hobbs TJ, Stol J, Drew A, Tongway $\mathrm{H}$ (1997) The effects of artificial sources of water on rangeland biodiversity. In 'Final report to the Biodiversity Convention and Strategy Section of the Biodiversity Group, Environment Australia'. Biodiversity technical paper no. 3. (Environment Australia and CSIRO: Canberra)

Landsberg J, James CD, Maconochie J, Nicholls AO, Stol J, Tynan R (2002) Scale-related effects of grazing on native plant communities in an arid rangeland region of South Australia. Journal of Applied Ecology 39, 427-444. doi:10.1046/j.1365-2664.2002.00719.x

Langdon JS (1989) Experimental transmission and pathogenicity of epizootic haematopoietic vecrosis virus (EHNV) in redfin perch Perca fluviatilis L. and 11 other teleosts. Journal of Fish Diseases 12, 295-310. doi:10.1111/ j.1365-2761.1989.tb00318.x

Latz P (1995) 'Bushfires \& bushtucker. Aboriginal plant use in Central Australia.' (IAD Press: Alice Springs, NT)

Lee Ligon B (2005) Avian Influenza Virus H5N1: a review of its history and information regarding its potential to cause the next pandemic. Seminars in Pediatric Infectious Diseases 16, 326-335. doi:10.1053/j.spid.2005. 07.002

Legge S, Murphy S, Heathcote J, Flaxman E, Augusteyn J, Crossman M (2008) The short-term effects of an extensive and high-intensity fire on vertebrates in the tropical savannas of the central Kimberley, northern Australia. Wildlife Research 35, 33-43. doi:10.1071/WR07016

Lehane L (1999) 'Ciguatera fish poisoning: a review in a risk assessment framework.' (National Office of Animal and Plant Health: Canberra)

Lindenmayer D, Fischer J (2006) 'Habitat fragmentation and landscape change: an ecological and conservation synthesis.' (Island Press: Washington, DC)

Lindenmayer DB, Hobbs RJ (Eds) (2007) 'Managing and designing landscapes for conservation: moving from perspectives to principles.' (Blackwell Publishing: Oxford, UK)

Loehle C, Li B (1996) Habitat destruction and the extinction debt revisited. Ecological Applications 6, 784-789. doi:10.2307/2269483

Lonsdale WM (1994) Inviting trouble: introduced pasture species in northern Australia. Australian Journal of Ecology 19, 345-354. doi:10.1111/ j.1442-9993.1994.tb00498.x

Lowe KW, Fitzsimons JA, Gleeson T, Straker A (2006) Seeking mechanisms for improved integration of biodiversity issues in regional natural resource management planning. Australasian Journal of Environmental Management 13, 52-61.

Lunney D (2001) Causes of the extinction of native mammals of the Western Division of New South Wales: an ecological interpretation of the nineteenth century historical record. The Rangeland Journal 23, 44-70. doi:10.1071/RJ01014

Lunt ID (2005) Effects of stock grazing on biodiversity values in temperate native grasslands and grassy woodlands in SE Australia: a literature review. Technical report 18. Environment ACT, Canberra.

Lunt ID, Spooner PG (2005) Using historical ecology to understand patterns of biodiversity in fragmented agricultural landscapes. Journal of Biogeography 32, 1859-1873. doi:10.1111/j.1365-2699.2005. 01296.x

Lunt ID, Eldridge DJ, Morgan JW, Witt GB (2007) Turner review no. 13. A framework to predict the effects of livestock grazing and grazing exclusion on conservation values in natural ecosystems in Australia. Australian Journal of Botany 55, 401-415. doi:10.1071/BT06178

Mac Nally R, Bennett AF, Thompson JR, Radford JQ, Unmack G, Horrocks G, Vesk PA (2009) Collapse of an avifauna: climate change appears to exacerbate habitat loss and degradation. Diversity \& Distributions 15, 720-730. doi:10.1111/j.1472-4642.2009.00578.x

MacLeod CJ, Moller H (2006) Intensification and diversification of New Zealand agriculture since 1960: an evaluation of current indicators of land use change. Agriculture Ecosystems \& Environment 115, 201-218. doi:10.1016/j.agee.2006.01.003
Mahr K (2009) Kangaroo: it's what's for dinner. Time Asia 173(19). Available at http://www.time.com/time/magazine/article/0,9171,18947 92,00.html [Verified 19 August 2010]

Martin T, McIntyre S (2007) Impacts of livestock grazing and and tree clearing on birds of woodland and riparian habitats'. Conservation Biology 21, 504-514. doi:10.1111/j.1523-1739.2006.00624.x

Martin TG, Campbell S, Grounds S (2006) Weeds of Australian rangelands. The Rangeland Journal 28, 3-26. doi:10.1071/RJ06017

McAlpine CA, Grigg GC, Mott JJ, Sharma P (1999) Influence of landscape structure on kangaroo abundance in a disturbed semi-arid woodland of Queensland. The Rangeland Journal 21, 104-134. doi:10.1071/ RJ9990104

McDougall S, Conallin J, Koelliker U, Hoffmann AA (1999) Biological pesticides and their effects on beneficial parasitic wasps. Australian Processing Tomato Grower 20, 35-38.

McIntyre S, Heard KM, Martin TG (2003) The relative importance of cattle grazing in subtropical grasslands - does it reduce or enhance plant biodiversity? Journal of Applied Ecology 40, 445-457. doi:10.1046/ j.1365-2664.2003.00823.x

McIvor JG, McIntyre SM, Saeli I, Hodgkinson JJ (2005) Patch dynamics in grazed subtropical native pastures in south-east Queensland. Austral Ecology 30, 445-464. doi:10.1111/j.1442-9993. 2005.01488.x

McKeon GM, Hall WB, Yee Yet Y, Stone GS, Crimp SJ, Peacock A, Richards R, Tynan RW, Watson IW, Power SB (Eds) (2004) 'Pasture degradation and recovery in Australia's rangelands. Learning from History.' (Queensland Department of Natural Resources, Mines and Energy: Brisbane)

McLaren C (1997) 'Dry sheep equivalents for comparing different classes of livestock.' Agricultural note AGO59. (Department of Primary Industries: Melbourne)

Meat \& Livestock Australia (2007a) 'Starting a dairy beef business. Business management tips and tools.' (Meat \& Livestock Australia: Sydney)

Meat \& Livestock Australia (2007b) 'Dairy beef calves - what makes a good one? Animal production tips and tools.' (Meat \& Livestock Australia: Sydney)

Mokany K, Friend D, Kirkpatrick J, Gilfedder L (2006) ‘Managing Tasmanian native pastures - a technical guide for graziers.' (Tasmanian Institute of Agricultural Research: Hobart)

Morgan G (2001) 'Landscape health in Australia.' (Natural Heritage Trust and National Land and Water Resources Audit: Canberra)

Morton SR, Stafford-Smith DM, Friedel MH, Griffin GF, Pickup G (1995) The stewardship of arid Australia: ecology and landscape management. Journal of Environmental Management 43, 195-217. doi:10.1016/ S0301-4797(95)90402-6

Murray-Darling Basin Commission (2008) 'The living Murray. Summary of progress. June 2004 - June 2008.' (Murray-Darling Basin Commission: Canberra)

Nastis A (1995) Feeding behaviour of goats and utilisation of pasture and rangelands. International Centre for Advanced Mediterranean Agronomic Studies (CIHEAM), Paris.

National Health and Medical Research Council (2003) 'Dietary guidelines for Australian adults.' (NRMC: Canberra)

National Land and Water Resources Audit (2001a) 'Australian agriculture assessment 2001, Vol. 2.' (Commonwealth of Australia: Canberra)

National Land and Water Resources Audit (2001b) 'Australian agriculture assessment 2001, Vol. 1.' (Commonwealth of Australia: Canberra)

National Land and Water Resources Audit (2002) 'Australian terrestrial biodiversity assessment 2002.' (National Land \& Water Resources: Canberra)

National Land and Water Resources Audit (2008) 'Land use - status of information for reporting against indicators under the National Natural Resource Management Monitoring and Evaluation Framework.' (National Land \& Water Resources Audit: Canberra) 
National Program for Sustainable Irrigation (2009) 'Planning tools: future scenarios and ecological risk assessments.' (Cotton Research and Development Corporation: Narrabri, NSW)

Noble JC, Habermehl MA, James CD, Landsberg J, Langston AC, Morton SR (1998) Biodiversity implications of water management in the Great Artesian Basin. The Rangeland Journal 20, 275-300. doi:10.1071/ RJ9980275

Norton T, Johannsohn N (2010) Alternatives to the use of 1080 program. Implications of browsing by native wildlife on improved pastures and native vegetation communities on King Island, Tasmania. Final report. TIAR, University of Tasmania, Hobart.

NSW Scientific Committee (2009a) Artesian springs endangered ecological community listing. (Department of Environment, Climate Change \& Water: NSW). Available at http://www.environment.nsw.gov.au/ determinations/ArtesianSpringsEcologicalCommunityEndComListing. htm [Verified May 2009]

NSW Scientific Committee (2009b) Competition and habitat degradation by feral goats key threatening process listing. (Department of Environment, Climate Change \& Water: NSW). Available at http://www.environment. nsw.gov.au/determinations/FeralGoatsKtp.htm [verified May 2009]

Olsen P, Low T (2006) Situation analysis report - update on current state of scientific knowledge on kangaroos in the environment, including ecological and economic impact and effect of culling. Prepared for the Kangaroo Management Advisory Panel. (NSW Department of Environment, Climate Change and Water: Sydney)

Organisation for Economic Co-operation and Development (1993) 'Core set of indicators for environmental performance reviews.' (OECD: Paris)

Owens FN, Gill DR, Secrist DS, Coleman SW (1995) Review of some aspects of growth and development of feedlot cattle. Journal of Animal Science 73, 3152-3172.

Pannell DJ (2005) Farm, food and resource issues: politics and dryland salinity. Australian Journal of Experimental Agriculture 45, 1471-1480. doi:10.1071/EA04158

Ponder W (2002) Desert springs of the Australian Great Artesian Basin. In 'Conference proceedings. Spring-fed wetlands: important scientific and cultural resources of the intermountain region'. Available at http://wetlands.dri.edu/2002/Ponder.pdf [Verified May 2009]

Powers W, Angel R (2008) A review of the capacity for nutritional strategies to address environmental challenges in poultry production. Poultry Science 87, 1929-1938. doi:10.3382/ps.2008-00090

Price RJ, Hacker RB (2009) Grain \& Graze: an innovative triple bottom line approach to collaborative and multi-disciplinary mixed-farming systems research, development and extension. Animal Production Science 49, 729-735. doi:10.1071/EA08306

Pringle H, Landsberg J (2004) Predicting the distribution of livestock grazing pressure in rangelands. Austral Ecology 29, 31-39. doi:10.1111/ j.1442-9993.2004.01363.x

Prober SM, Thiele KR, Lunt ID (2002) Identifying ecological barriers to restoration in temperate grassy woodlands: soil changes associated with different degradation states. Australian Journal of Botany 50, 699-712. doi:10.1071/BT02052

Queensland Environmental Protection Authority (2006) Queensland water quality guidelines. Available at http://www.epa.qld.gov.au/ environmental_management/water/queensland_water_quality_guidelines/ index.html\#gen0 [Verified 28 June 2009]

Quirk MF, McIvor JG (2003) 'Grazing land management-technical manual.' (Meat \& Livestock Australia: Sydney)

Radford JQ, Bennett AF, Cheers GJ (2005) Landscape-level thresholds of habitat cover for woodland-dependent birds. Biological Conservation 124, 317-337. doi:10.1016/j.biocon.2005.01.039

reefED (2009) Human impacts - water quality. reefED website. An initiative of the Great Barrier Reef Marine Park Authority. Available at http://www. reefed.edu.au/home/explorer/hot_topics/water_quality/human_impacts [Verified June 2009]
Richter BD, Baumgartner JV, Wigington R, Braun DP (1997) How much water does a river need? Freshwater Biology 37, 231-249. doi:10.1046/ j.1365-2427.1997.00153.x

Robertson AI, Rowling RW (2000) Effects of livestock on riparian zone vegetation in an Australian dryland river. Regulated Rivers: Research and Management 16, 527-541. doi:10.1002/1099-1646(200009/10) 16:5<527::AID-RRR602>3.0.CO;2-W

Röling N (2003) From causes to reasons: the human dimension of agricultural sustainability. International Journal of Agricultural Sustainability 1, 73-88. doi:10.3763/ijas.2003.0108

Rural Industries R\&D Corporation (2009) New animal products program. Available at http://www.rirdc.gov.au/programs/new-rural-industries/ new-animal-products/program-overview/program-overview_home.cfm [Verified 4 July 2009]

Savory A, Butterfield J (1999) 'Holistic management. A new framework for decision making.' 2nd edn. (Island Press: Washington, DC)

Smyth A, Freidel M, Malley CO (2009) The influence of buffel grass (Cenchrus ciliaris) on biodiversity in an arid Australian landscape. The Rangeland Journal 31, 307-320. doi:10.1071/RJ08026

Spragg J (2008) Benefits to Australian grain growers in the feed grain market. A report for the Grains Research and Development Corporation. (JCS Solutions, GRDC: Canberra)

Staton J, O'Sullivan J (2006) 'Stock and waterways: a manager's guide.' (Land \& Water Australia: Canberra)

Steffen W, Burbidge AA, Hughes L, Kitching R, Lindenmayer D, Musgrave W, Stafford-Smith M, Werner PA (2009) Australia's biodiversity and climate change. A strategic assessment of the vulnerability of Australia's biodiversity to climate change. A report to the Natural Resource Management Ministerial Council commissioned by the Australian Government. CSIRO Publishing, Melbourne.

Steinfeld H, Gerber P, Wassenaar T, Castel V, Rosales M, De Haan C (2006) 'Livestock's long shadow: environmental issues and options.' (FAO: Rome)

Steinfeld H, Mooney HA, Schneider F, Neville LE (2010) 'Livestock in a changing landscape. Vol. 1. Drivers, consequences and responses.' (Scientific Committee on Problems of the Environment (SCOPE): Paris)

Stoneham G (2007) 'Creating markets for environmental goods and services: a mechanism design approach.' Senior Fellowship report. (Land \& Water Australia: Canberra)

Stringer R, Anderson K (2001) Australia. In 'Public concerns, environmental standards and agricultural trade'. (Eds F Brouwer, D Ervin) pp. 181-215. (CABI Publishing: Wallingford, UK)

Tasker E, Bradstock R (2006) Influence of cattle grazing on forest understorey structure in north-eastern New South Wales. Austral Ecology 31, 490-502. doi:10.1111/j.1442-9993.2006.01597.x

Tilman D, May RM, Lehman CL, Nowak MA (1994) Habitat destruction and the extinction debt. Nature 371, 65-66. doi:10.1038/371065a0

Ucar T, Hall FR (2001) Windbreaks as a pesticide drift mitigation strategy: a review. Pest Management Science 57, 663-675. doi:10.1002/ps.341

Valentine JF (2001) 'Grazing management.' (Academic Press: San Diego)

Valzano FP, Greene RSB, Murphy BW (1997) Direct effects of stubble burning on soil hydraulic and physical properties in a direct drill tillage system. Soil \& Tillage Research 42, 209-219. doi:10.1016/S0167-1987 (96)01101-4

Verbeke W, van Oeckel MJ, Warnants N, Viaene J, Boucque CV (1999) Consumer perception, facts and possibilities to improve acceptability of health and sensory characteristics of pork. Meat Science 53, 77-99. doi:10.1016/S0309-1740(99)00036-4

Vesk P, Mac Nally R (2006) The clock is ticking - revegetation and habitat for birds and arboreal mammals in rural landscapes of southern Australia. Agriculture Ecosystems \& Environment 112, 356-366. doi:10.1016/ j.agee.2005.08.038 
Viggers K, Hearn JP (2005) The kangaroo conundrum: home range studies and implications for land management. Journal of Applied Ecology 42, 99-107. doi:10.1111/j.1365-2664.2005.01001.x

Wagg M, Lawson A, Pattinson P (2007) Land, Water \& Wool: program management report. Land \& Water Australia, Canberra.

Wahren CHA, Papst WA, Williams RJ (1994) Long-term vegetation change in relation to cattle grazing in Sub-Alpine grassland and heathland on the Bogong High-Plains: an analysis of vegetation records from 1945 to 1994. Australian Journal of Botany 42(6), 607-639. doi:10.1071/BT9940607

Waters C, Hacker R (2008) Literature review and recommendations for the integration of biodiversity and primary production in northern and western New South Wales. NSW DPI, Orange, NSW.

Whelan R (1995) 'The ecology of fire.' Cambridge studies in ecology. (Cambridge University Press: London)

Whitten S, Coggan A, Reeson A, Shelton D (2009) Market based instruments for ecosystem services in a regional context. RIRDC publication no. 08/ 196. RIRDC, Canberra.

Wiedemann SG, Davis RJ, Zadow EN, McGahan EJ, Watts PJ, Nielson WM, Cottle D, Martin P (2009) Review of GHG and water in the red meat industry-report 1. Meat \& Livestock Australia Project B CCH 2022. Meat \& Livestock Australia, Sydney.

Williams P, Collett A (2009) Control of the exotic para grass allows the expansion of the rare native wetland grass Paspalidium udum in a north Queensland wetland. Ecological Management \& Restoration 10, 60-62. doi:10.1111/j.1442-8903.2009.00440.x

Williams JE, Goodacre M (2008) Profitable and biodiverse wool production: the Land, Water \& Wool program. In 'Biodiversity: integrating conservation and production. Case studies from Australian farms, forests and fisheries'. (Eds T Lefroy, K Bailey, G Unwin, T Norton) pp. 177-185. (CSIRO: Melbourne)

Williams JE, Price RJ (2008) 'Evaluation of responses to threats to Australia's biodiversity.' (National Land \& Water Resources Audit: Canberra)

Williams JE, Price RJ (2009) Review of the impact of red-meat production and alternative sources of protein on biodiversity. Final report to Meat \& Livestock Australia. Report no. BCCH2023. Meat \& Livestock Australia, Sydney.
Williams JE, Read C, Norton T, Dovers S, Burgman M, Proctor W, Anderson H (2001) Biodiversity, Australia State of the Environment report (theme report) (2001). CSIRO Publishing on behalf of the Department of Environment and Heritage, Melbourne.

Williams RJ, Henrikwahren C, Bradstock RA, Muller WJ (2006) Does alpine grazing reduce blazing? A landscape test of a widely held hypothesis. Austral Ecology 31, 925-936. doi:10.1111/j.1442-9993.2006.01655.x

Williams M, Woods M, Kumar A, Guo Ying G, Shareef A, Karkkainen M, Kookoona R (2007) 'Endocrine disrupting chemicals in the Australian riverine environment: a pilot study on estrogenic compounds.' (Land \& Water Australia: Canberra)

Wilson G, Edwards M (2008) Roo diet placed on greenhouse menu. Australasian Science October, 36-37.

Woinarski JCZ, Ash A (2002) Responses of vertebrates to pastoralism, military land use and landscape position in an Australian tropical savanna. Austral Ecology 27, 311-323. doi:10.1046/j.1442-9993.2002. 01182.x

Woinarski JCZ, Williams RJ, Price O, Rankmore B (2005) Landscapes without boundaries: wildlife and their environments in northern Australia. Wildlife Research 32, 377-388. doi:10.1071/WR03008

Woinarski JCZ, Mackey B, Nix H, Traill B (2007) 'The nature of northern Australia. Natural values, ecological processes and future prospects.' (ANU EPress: Canberra)

Worm B, Hilborn R, Baum JK, Branch TA, Collie JS, Costello C, Fogarty MJ, Fulton EA, Hutchings JA, Jennings S, Jensen OP, Lotze HK, Mace PM, McClanahan TR, Minto C, Palumbi SR, Parma AM, Ricard D, Rosenberg AA, Watson R, Zeller D (2009) Rebuilding global fisheries. Science 325, 578-585. doi:10.1126/science. 1173146

Yates C, Norton DA, Hobbs RJ (2000) Grazing effects on plant cover, soil and microclimate in fragmented woodlands in south-western Australia: implications for restoration. Austral Ecology 25, 36-47.

Manuscript received 6 October 2009, accepted 8 June 2010 